\title{
Impact of attribution retraining with students enrolled in an Internet-based instructional technology course at a community college
}

\author{
Bonnie McCall Ordonez \\ West Virginia University
}

Follow this and additional works at: https://researchrepository.wvu.edu/etd

\section{Recommended Citation \\ McCall Ordonez, Bonnie, "Impact of attribution retraining with students enrolled in an Internet-based instructional technology course at a community college" (2008). Graduate Theses, Dissertations, and Problem Reports. 2842. \\ https://researchrepository.wvu.edu/etd/2842}

This Dissertation is protected by copyright and/or related rights. It has been brought to you by the The Research Repository @ WVU with permission from the rights-holder(s). You are free to use this Dissertation in any way that is permitted by the copyright and related rights legislation that applies to your use. For other uses you must obtain permission from the rights-holder(s) directly, unless additional rights are indicated by a Creative Commons license in the record and/ or on the work itself. This Dissertation has been accepted for inclusion in WVU Graduate Theses, Dissertations, and Problem Reports collection by an authorized administrator of The Research Repository @ WVU.

For more information, please contact researchrepository@mail.wvu.edu. 
Impact of Attribution Retraining with Students Enrolled in an Internetbased Instructional Technology Course at a Community College

Bonnie McCall Ordonez

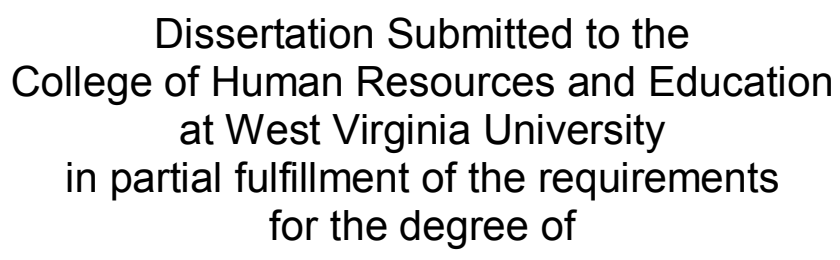

Doctor of Education

in

Technology Education

R. Neal Shambaugh, Ph.D., Chair

Dan Hartley, Ed. D.

Patricia Haught, Ed.D.

D.J. Hendricks, Ed.D.

Cheryl L. Prichard, Ed. D.

Department of Technology, Learning, and Culture

\author{
Morgantown, West Virginia \\ 2008
}

Keywords: attribution, locus of control, self-efficacy, distance learning, retention, community college

Copyright 2008 Bonnie McCall Ordonez 


\begin{abstract}
Impact of Attribution Retraining with Students Enrolled in an Internet-based Instructional Technology Course at a Community College

Bonnie McCall Ordonez
\end{abstract}

This study explores the use of attribution retraining in a community college, distance learning course. Attribution training is a form of psychotherapy used in an attempt to shift an individual's attitude, motivation, and locus of control (LOC).

Locus of control is a measure of how one attributes success and failure. Those with internal locus of control believe they are responsible and control their fate while those with external locus of control tend to look for fault outside of themselves.

The purpose of the study was to examine the impact of attribution training, which consisted of a multimedia, interactive intervention called Just Think It, on an online instructional technology course. The research questions examined the impact of attribution retraining on locus of control scores, grade point average, and course retention. Little research has been done on the use of attribution retraining to alter locus of control in a distance learning environment.

The participants consisted of students enrolled in the online course, EDU202 Instructional Technology in the summer and fall 2007 semesters. A quasi- experimental research design was used whereas treatment and control groups were each given a pre and posttest using Rotter's LOC survey. The treatment group received the intervention and the control group did not. Results were compared along with final grade averages and course retention statistics.

Results indicated that no significant change existed as the result of the intervention for locus of control or grade point average. However, course retention rates proved to be slightly higher for the treatment group than those of the control group. 


\section{ACKNOWLEDGEMENTS}

I would like to thank my committee members; Dan Hartley, Ed. D., Patricia Haught, Ed.D., D.J. Hendricks, Ed.D., and Cheryl L. Prichard, Ed. D, for their support. Most especially, thank you to Dr. Neal Shambaugh for stepping into the role as Committee Chair. l'd like to acknowledge and thank my colleagues and friends at CCAC for their empathy. Steve, Je, and Donna, I appreciate your friendship and the prodding. And finally I would like to thank my family and friends for your love and patience. Chrissy, Danielle, Kim, and Alicia, thank you for letting me complain and always understanding. Thanks to my husband, Rick, who supported me all the way and our kids, Madison and Christian. I hope you can be as proud of mom as I am of you. I will never miss another game, concert, school event, or activity again. And finally, I want to dedicate this dissertation to my mom for showing me how to be a strong, determined woman. 


\section{TABLE OF CONTENTS}

ACKNOWLEDGEMENTS

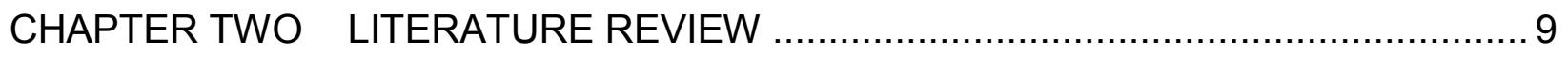

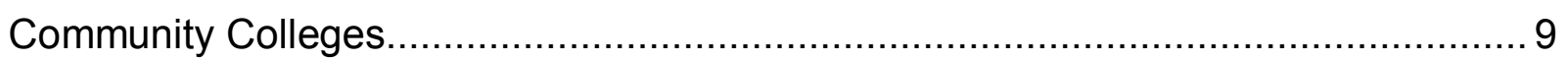

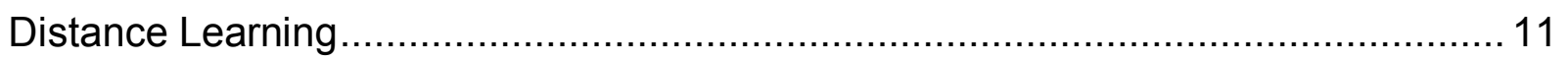

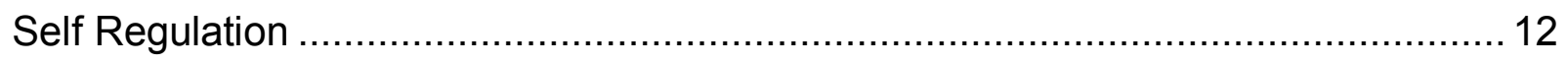

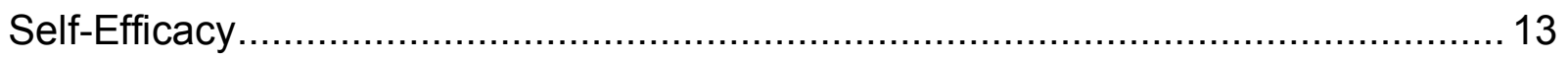

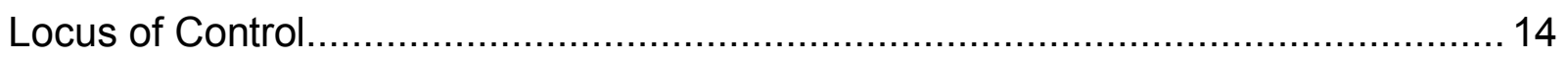

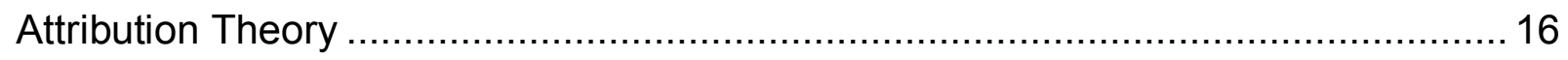

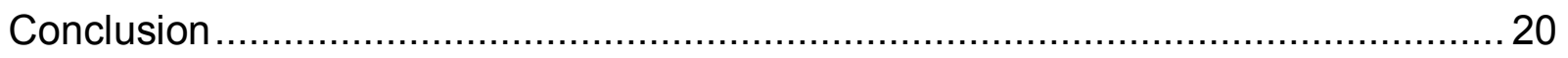

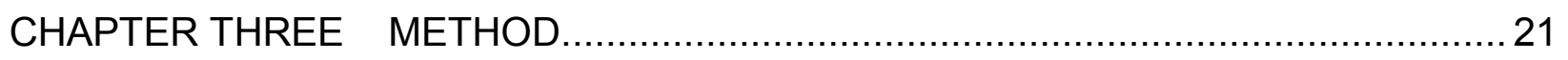

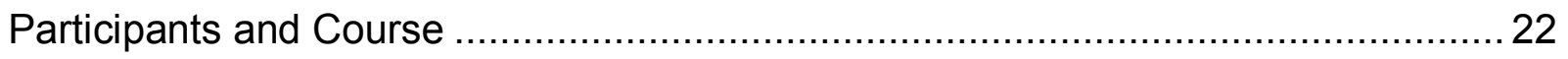

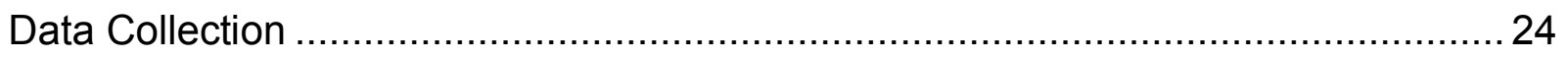

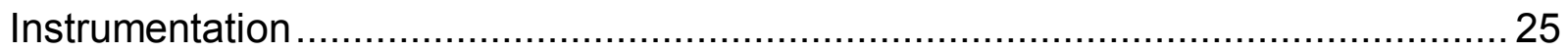




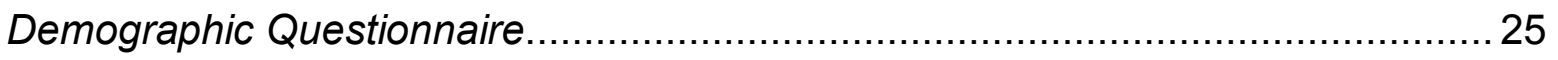

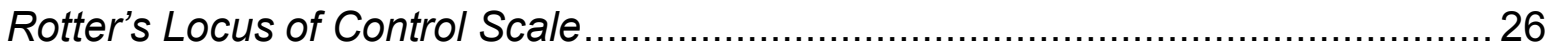

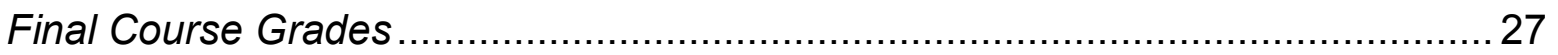

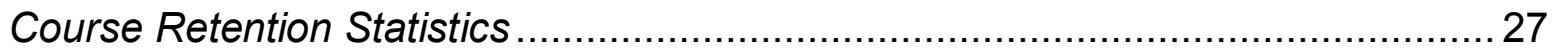

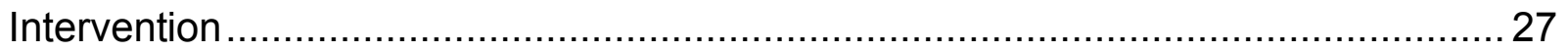

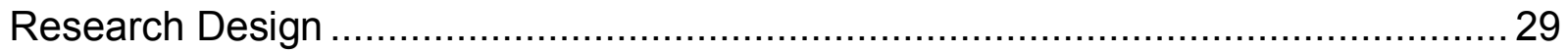

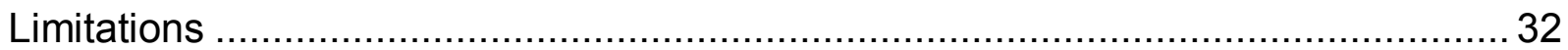

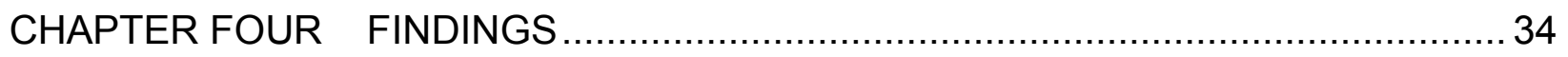

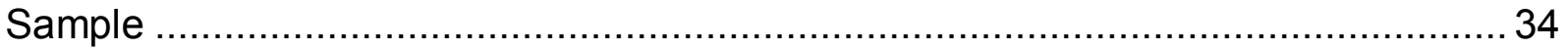

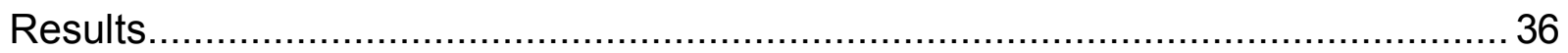

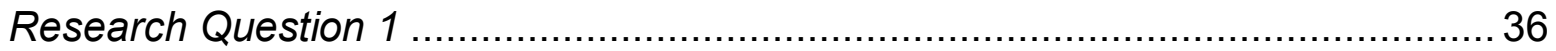

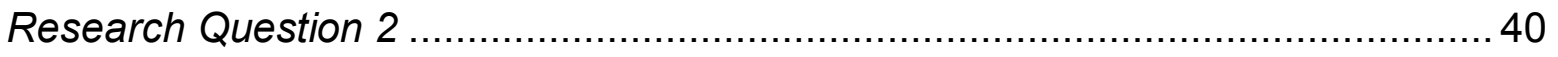

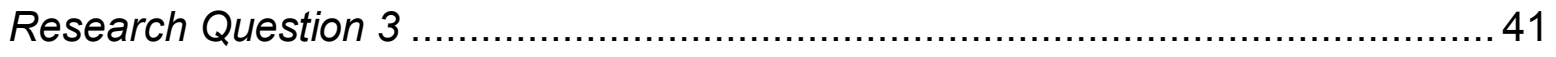

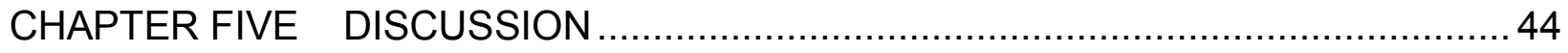

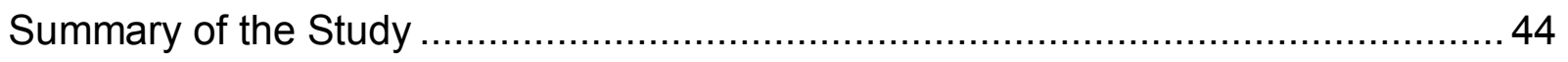

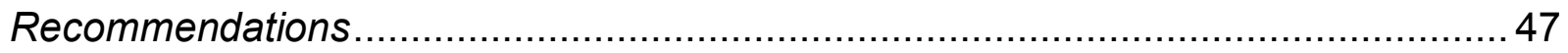

Recommendations for Community Colleges ................................................ 48

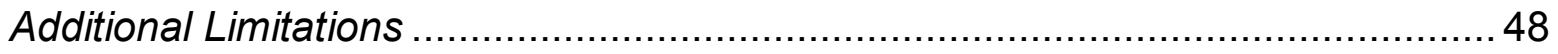

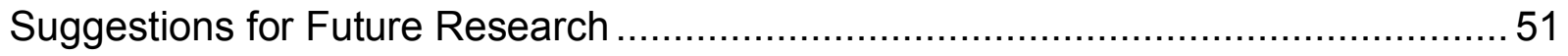

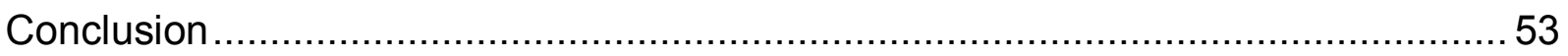

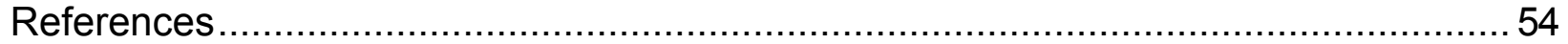

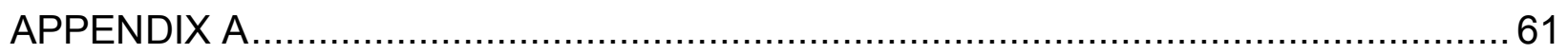

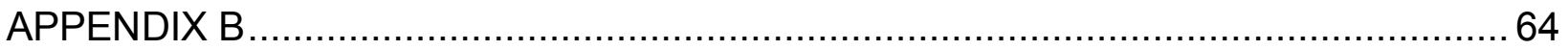




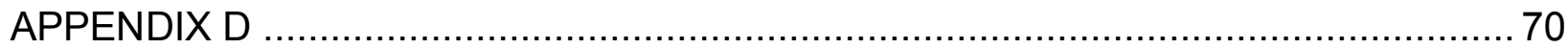

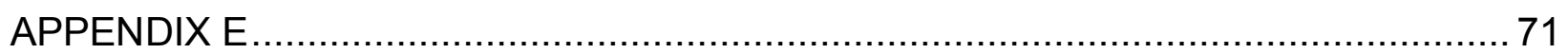




\section{LIST OF TABLES}

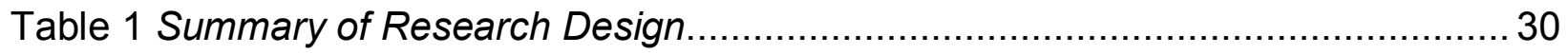

Table 2 Research Questions, Data Sources, and Analysis Procedures....................... 32

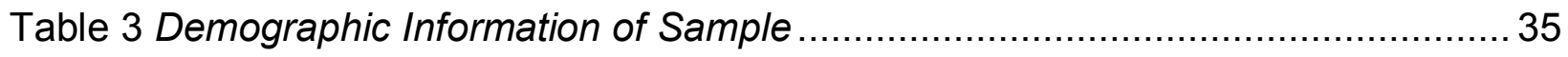

Table 4 Locus of Control Pretest and Posttest Treatment Group................................ 38

Table 5 Locus of Control Pretest and Posttest Control Group.................................... 38

Table 6 Repeated Measures T-test Treatment Group.............................................. 39

Table 7 Repeated Measures T-test Control Group................................................ 40

Table 8 Frequency Count of Grades in Treatment and Control Groups...................... 41

Table 9 Grade Point Average of Entire Sample ......................................................... 41

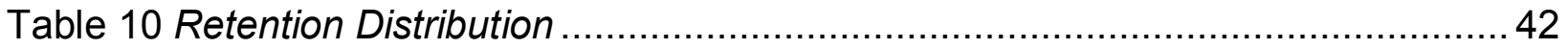

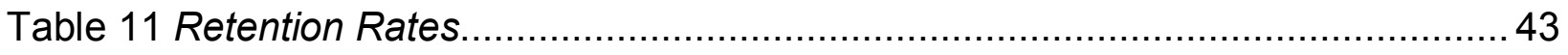




\section{CHAPTER ONE}

\section{INTRODUCTION}

Community colleges across the United States are struggling to retain students. Student retention rates are often used to assess the effectiveness of an academic institution. The Lumina Foundation (2004) reports, "Nearly half of all students enrolled in a community college fail to complete their post secondary education." Student retention impacts the individual student, college faculty, staff, and administrators, as well as the community (Muse, 2005). Students who fail to complete their education find themselves in lower paying jobs, contributing less in tax dollars. In addition, non-completers limit the amount of skilled workforce. Considering that community colleges receive government funding, retention rates may impact budgets (Parker, 1999). Many community colleges look to making institutional changes to combat the attrition problem. Researchers, such as Tinto (2002), call for changes in advising, student support services, entry assessment and early warning systems, and academic and social integration programs. However, academic institutions in looking to a macro solution often overlook a micro solution. Individual course completion and persistence has a major impact on program retention (Tinto, 2002). Oftentimes if a student fails or drops an individual course, it has a negative effect on program completion.

In examining course completion and persistence, it is important to specify the format of the course delivery. Traditional face-to-face courses experience different retention rates than online courses. Distance education courses have routinely suffered from low retention. According to Nash (2005), "Educators continue to report course drop out and failure rates among distance learners that are significantly higher than those for 
traditional, campus-based students." Carr (2000) points out that many college administrators report distance education course completion rates are consistently 10 to 20 percent lower than established face-to-face courses.

Student characteristics also play a role in course completion. Looking to what drives the individual student to complete a course may shed some light on the larger issue of academic persistence. Retention and academic success have been correlated to the individual student's self regulation and more specifically internal locus of control (Rotter, 1966). Locus of control in education refers to how a student attributes their success and failure. Students who display an internal locus of control recognize their successes and failures are in their control while students with an external locus of control often attribute success or failure to something outside of their control (Lynch, Hurford, \& Cole, 2002). Research demonstrates the correlation between low internal locus of control and drop-out rates (Dille \& Mezack, 1991). Parker (1999) found that, along with the inability to locate financial assistance, locus of control was a major factor in predicting a student's success in a distance education course.

Attribution retraining (AR) has been shown to improve internal locus of control in a traditional environment (Hall, Hladkyj, Perry, \& Ruthig, 2004). Warring (1991) states, "Attribution is often defined as the way we assign causes to events" (p. 179). Attribution retraining helps students identify and adopt plausible reasons for success and failure that focus on controllable behavior modification. In short, AR can impact modifiable behaviors that can improve performance and course retention (Hall et al., 2004). Attribution retraining can take different forms including video intervention, emotive writing, study skills training, and elaborative learning (Perry \& Penner, 1990). 


\section{Problem Statement}

Distance learning courses are on the rise but achievement and retention in these courses continues to decline (Parker, 2003). While many factors have been identified, community colleges look for strategies to improve achievement and course retention for the distance learning student. Face-to-face student orientations, tutors, and improved training for distance learning faculty have demonstrated moderate success (Nash, 2005).

Despite these efforts, many students continue to struggle in courses offered in an online platform. Self regulation, self-efficacy, motivation, and locus of control research demonstrate a strong correlation to a student's academic success and persistence in a traditional environment. Years of research in a variety of academic settings confirm the success of attribution retraining for students with low motivation and high external locus of control (Hall et al., 2004). However, very few in-depth studies have looked at attribution retraining for distance learning students.

\section{Need for the Study}

Community college administrators are seeking practical solutions for student retention and success for budgetary and funding reasons. In addition, as distance learning programs continue to grow, administrators will need to review and compare their effectiveness to traditional courses.

College faculty members invest a great deal of time in Internet course development and look to retain students and/or determine why students drop out, withdraw, or fail. Distance learning courses continue to suffer from high attrition rates. Community colleges are particularly vulnerable to attrition due to the demographic 
makeup of the student population (Muse, 2005). Community colleges service more nontraditional, minority and at-risk students, along with many first generation college attendees.

Community college students tend to have different socioeconomic challenges than students enrolled in four year schools, being that they often fall into lower socioeconomic levels, which can lead to higher drop out rates (Wild \& Ebbers, 2002). In addition, most students at a community college are commuters rather than living on campus, causing lower class attendance. Students often feel overwhelmed by Internet courses and may present a low internal locus of control (Parker, 1999). Students suffer a sense of failure when dropping out of one course which may impact future enrollment and further decrease internal locus of control. Retaining these students to graduation contributes to the workforce as well as the number of viable candidates who will continue on for four-year degrees. In addition, improving internal locus of control may contribute to future success in college as well as in the workforce (Dille \& Mezack, 1991; Parker, 1999).

Community colleges have implemented a variety of institutional changes to combat the problem of course attrition. Student orientations and tutoring services have proven to be moderately successful in retaining students (Nash, 2005). However, distance learning courses continue to have lower retention rates than traditional face-toface courses. Institutional changes do impact retention; however, academic institutions often overlook the needs and characteristics of the individual student in the distance learning environment. 
Attribution retraining has been used for years in the $\mathrm{K}-12$ and special education environments (Schunk, 2003). While some research is available on self regulation, selfefficacy, motivation, and locus of control in a distance learning environment, virtually no research exists on the impact of attribution retraining with community college distance learning students. If results of attribution retraining in the distance learning environment prove favorable, community colleges will have another inexpensive tool at their disposal to apply in efforts to retain students and improve academic achievement.

\section{Purpose of Study}

The purpose of this study is to evaluate the potential of an attribution retraining intervention in improving a student's internal locus of control, academic achievement (final course grades), and course retention in a distance learning environment at the Community College of Allegheny County. The study will examine an attribution retraining treatment in the form of an interactive, multi-media intervention, along with a control group of students who will receive no attribution retraining, to determine any significant difference in the impact on internal locus of control, final course grades, and course retention.

\section{Research Questions}

This study will examine the impact of attribution retraining on locus of control, academic achievement (final course grades), and course retention. The following research questions will be investigated: 
Research Question 1: Does attribution retraining (an interactive multi-media intervention), implemented in Internet courses, change a student's internal locus of control?

Research Question 2: Does attribution retraining (an interactive multi-media intervention) implemented in Internet courses demonstrate a significant difference in achievement (final course grades) for the course EDU202 Instructional Technology? Research Question 3: Does attribution retraining (an interactive multi-media intervention) implemented in Internet courses demonstrate a change in course retention?

\section{Definition of Terms}

The following terms were used and defined within the context of this study. Academic Achievement. Final course grades as determined by the instructor based on various class assignments will constitute the achievement measures.

Act 48: Pennsylvania Act 48 is a certification requirement for which all Pennsylvania certified educators must participate in ongoing professional education to maintain a current education certificate.

Asynchronous. Asynchronous refers to a distance learning course where the instructor and students do not communicate in real time, but through tools such as email and discussion board postings.

Attribution. The term is defined as the manner in which one rationalizes the cause of events.

Attribution Retraining. AR, as it is commonly referred, is a form of psychotherapy that presents interventions to improve locus of control, motivation, and achievement. 
Attrition. The term refers to the reduction of enrollment numbers in a given course section.

Distance Learner. A student who is taking a course completely via the Internet is considered a distance learner.

External Locus of Control. A person who attributes their success or failure to outside forces, such as luck or task difficulty, are said to have an external locus of control. Face- to-Face Instruction. Traditional classroom instruction where the student and instructor meet in the same room on a regularly scheduled basis is considered face-toface instruction.

Internal Locus of Control. A person who attributes their success or failure to circumstances within their control, such as their own effort or ability, are said to have an internal locus of control.

Intervention. The term intervention is the implementation of a purposeful action to elicit change.

Locus of Control. LOC or Locus of Control is an individual's belief system which demonstrates the manner in which an individual attributes success and failure. Persistence. The term refers to students who remain in a course throughout an academic term (students who do not drop, withdraw, or fail a course).

Retention. Course retention refers to the number of students who begin and end a course to completion. Program retention refers to the number of students who begin and end a program of study to completion. Degree retention is the number of students who begin and end an academic program completion and receive a degree. 
Self-efficacy. Bandura (1994) defines as "people's beliefs about their capabilities to produce designated levels of performance that exercise influence over events that affect their lives."

Self regulation. The term refers to a person who actively (socially, behaviorally, motivationally) participates in his or her own learning and problem solving through self observation. 


\section{CHAPTER TWO}

\section{LITERATURE REVIEW}

\section{Community Colleges}

Community colleges have long served a special niche in higher education. With a unique population, community colleges play a vital role in providing access to higher education for those who might not otherwise have the opportunity to attend college. Community colleges enroll almost half (44\%) of all undergraduates (Wild \& Ebbers, 2002). Community colleges serve the underserved. Statistically, community colleges enroll more low income and minority students than four-year colleges and universities. They also have more first generation college attendees than four-year schools (Lotkowski, Robbins, \& Noeth, 2004).

Many other aspects make the community college different. Students attending a community college often enroll with a variety of goals. Some students are interested in work force training, while others are seeking a one-year certificate, and still others are pursuing two-year associate degrees. In addition, many community college enrollees are already students at four-year colleges and enroll in community colleges on a course by course basis to save money and hasten their degree completion. Retaining community college students is a difficult task that is further complicated by the lack of reliable tracking methods (Wild \& Ebbers, 2002). A significant number of research studies have been focused on retention and attrition rates and while the methods differ, the results vary little. Less than $50 \%$ of students complete degrees and programs of study (Wild \& Ebbers, 2002; Zamani, 2000). Graduation rates range form 34.3\% to $44 \%$ Lotkowski, Robbins, \& Noeth, 2004). Rates are even lower for students of color, who 
make up a significant portion of community college enrollees. Statistics vary but have been measured as low as 26 - 28\% (Lumina Foundation, 2004).

Retention at a community college typically refers to the completion of student outcomes and enrollment in consecutive semesters (Goel, 2002). Research addressing attrition and retention cites differing factors for why some students succeed and others do not. Upcraft, Gardener, and Associates (1989) found the following characteristics impact student success: personal, demographic, cultural, institutional characteristics and climate. Tinto (1998) identified conditions for retention which include: expectations, support, feedback, involvement, and learning. Pantages and Creedon's (1978) research established that these variables have the greatest impact on retention: financial, health, demographic, motivational, academic, personality, and the environment at the college. Retention rates reflect on the quality and effectiveness of an institution. Despite low retention rates, a leading researcher in the field of community college retention, Vincent Tinto (1999) asserts many two and four-year colleges "have not taken student retention seriously." He is critical of the current retention programs and strategies implemented at community colleges. "To be serious about student retention, institutions would recognize that the rates of attrition lie not only in their students and the situations they face, but also in the very character of the educational settings" (p. 5). Historically, schools have jumped to make institutional changes such as: freshmen seminar classes, advising, and other "add-on services" (Tinto, 1993). This disconnect of services has proven to have little success. In addition, schools often overlook the needs of the individual student in lieu of a one size fits all approach. Budgetary constraints and limited resources are often cited as the rationale for this approach (Tinto, 1993). 
Student retention and attrition is further complicated with the addition of distance learning courses and programs. Distance learning has exploded at community colleges and four-year schools alike (Valentine, 2002). Along with this new wave of courses, comes a new set of issues with student retention.

\section{Distance Learning}

Distance learning can be defined as any learning opportunity where the student and instructor are not in the same geographic location and may be separated by time. Many forms of distance learning exist. Recently, internet courses have been the main delivery method for distance education (Valentine, 2002). In many cases, students access their courses through an online courseware package such as Blackboard Learning Systems. The student logs into a secure site and can access course materials, discussion boards, chat windows, and a variety of other course tools.

Retention issues are not unique to traditional, face-to-face courses. Course format has been shown to have a significant impact of course retention (Serwatka, 2005). While the data vary, research indicates distance education courses have significantly lower retention rates than traditional face-to-face courses (Carr, 2000; Stover, 2005). Allen and Seaman (2004) state that many online courses are not wellsuited to the individual student and student success. They list three reasons to support this assertion: (1) online courses distance students from various aspects of academic integration, (2) online courses limit opportunities for social engagement, and (3) online courses distance students from learning and relationship building. Despite these criticisms, college administrators continue to increase online course offerings. Researchers continue to search for solutions to increase retention and academic 
success in distance learning. Parker (1999) examined financial aid as a variable in distance education retention. Carr (2000) researched the experience level of the instructor. Others have looked to student characteristics to explain attrition and persistence in distance education. Byers (2000) and Serwatka (2005) note interaction is the key to a successful online experience. Diaz and Cartnal (1999) studied learning styles as the main consideration in online student success. Berge and Huang (2004) created a model for distance learning retention which included "circumstantial variables" such as stress and satisfaction levels. Indeed, the human element tends to yield significant data demonstrating the impact on retention and academic success. In any academic setting, especially a distance learning environment, self regulation and self efficacy is essential. In addition, a small, but growing, body of research has begun to explore locus of control in distance learning (Liu, Lavelle, \& Andris, 2002; Stone, 1992).

Self Regulation

According to Schunk and Zimmerman (2007), "self regulation refers to self generated thoughts, feelings, and actions that are systematically designed to affect one's learning of knowledge and skills" (p. 8). Self regulation ties to locus of control as both relate to attributional styles (Dresel \& Haugwitz, 2006). Attributions refer to how an individual assesses why things happen. Several research studies have been conducted on self regulation, locus of control, and attributions. Dresel and Haugwitz (2006) utilized computer generated motivational training in mathematics software, based on attributional feedback, in hopes of positively impacting student's self regulated learning. They were successful. Three groups of students made up the sample with one receiving the attribution feedback, the second received attributional feedback and self regulation 
training, and the third group received neither. The attributional feedback along with additional self regulation training promoted motivation and better knowledge acquisition in middle school students. Whipp and Chiarelli (2004) studied self regulation in webbased courses and found results supporting self regulation in a web-based environment. They concluded that the successful students "demonstrated a number of significant adaptations of SRL (self-regulated learning) strategies to fit their Web-based environment" (p. 11). Traditional strategies include the use of calendars and planners for planning with the online adaptation being daily log-ons. Note taking in a traditional environment was adapted to printing out course materials in an online environment. In a traditional environment record keeping would consist of charts to track grades but adapted to the online environment would be checking of the online grade book and frequently backing up work (Whipp \& Chiarelli, 2004).

A self regulated learner is an active participant in the learning process based on self efficacy. Self regulators display strong self attributions which is also a key component in locus of control. Therefore, one might consider promoting self regulation techniques through attributional retraining to facilitate an increase in internal locus of control.

\section{Self-Efficacy}

Albert Bandura (1994) defines self-efficacy as "people's beliefs about their capabilities to produce designated levels of performance that exercise influence over events that affect their lives" (p. 71). Similar to locus of control, level of self-efficacy can be linked to academic achievement and persistence. Personal efficacy can be tied to several processes including: cognitive, motivational, affective, and selection (Bandura, 
1994). Taking these processes into consideration, Heaperman and Sudweeks (2002) listed ways to encourage strong self-efficacy beliefs in a virtual learning environment. Creating an environment that fosters awareness, peer support, structure, and coping strategies are just a few ways to foster positive self-efficacy. The utilization of these strategies, along with attribution retraining, may prove helpful in altering student's locus of control and success in a distance learning environment.

\section{Locus of Control}

Locus of control (LOC) is a psychological construct which identifies a person's perceptions of control (Grimes, Millea, \& Woodruff, 2004; Rotter, 1966). Locus of control is characterized by internal and external measures. A person with internal locus of control tends to view success or failure as being controlled by their individual actions and behaviors. A person with external locus of control views success and failure as being outside of their control (Lynch, Hurford, \& Cole, 2002).

One's locus of control is developed in a variety of ways. Research indicates that locus of control is a learned behavior (Neill, 2005). Others believe locus of control is an "inherited trait" that is "likely to be linked to cerebral functioning" (Grimes et al., 2004). Past experiences and family background have been shown to have an impact on locus of control. Culture may also impact locus of control. Experiences that focus on rewards tend to most directly impact a subject's internal or external locus of control. Families who demonstrate a high degree of internal attribution often pass on internal locus of control through modeling. While families who enable children and do not allow opportunities for independence tend to raise external-oriented offspring (Lynch et al., 2002). 
Locus of control can impact an individual in a variety of ways. Grimes et al. (2004) correlates LOC to the way one acquires knowledge, processes feedback, copes with stress, and engages in interpersonal relationships. Locus of control has gained considerable attention in many aspects of academics; including academic achievement, along with persistence and retention (Grimes et al., 2004; Keller, Goldman, \& Sutterer, 1978; Parker, 1999; Schultz \& Pomerantz, 1976).

Stone (1992) and Parker (2003) attempted to correlate locus of control with distance education course persistence and completion rates. Both studies found some correlation between a student's academic persistence and his/her locus of control. Grimes et al. (2004) took a different approach in researching the impact of locus of control on student evaluations of teaching. Their study, which used Weiner's attribution theory, demonstrated a correlation between locus of control and the way in which students evaluated their instructor. Keller et al. (1978) study found LOC was more closely related to academic attitudes rather than academic performance. Dollinger (2000) took a different approach and compared how internal and external students differ in their retention of incidental or trivial knowledge. He tested his subjects on information that students could have learned in the course syllabus, such as instructor's office hours, and off hand comments he made in class such as asking the name of colleague's wife. His study supported much of the literature, demonstrating that students with internal locus of control far exceed students with external locus of control in retaining incidental knowledge which can then be applied to academic achievement.

Locus of control is often referred to as a "causal dimension" of attribution behavior (Weiner, 1979). While demonstrating some stability, locus of control can 
change with intervention, such as attribution retraining. Chen (2005) identified several other models that prove effective for changing psychological constructs, including locus of control. The heuristic and learning models were two which Chen found to be successful. Chen goes on to point out that "students may change their own psychological constructs through self-perception and response to the processes of mixed models" (p. 48). The goal of change is to shift from an external locus of control, where a student attributes their success or failure to factors outside of their control, to internal locus of control, where a student realizes the causal dimension of success and failure is within their control. Legerski, Cornwall, and O'Neil (2006) confirmed the relative stability of locus of control in their study looking at unemployed steel workers. However, they also noted "locus of control changes over time." Haggbloom (2002), in his biography featuring Julian Rotter and other psychologists, points out that Rotter was a firm believer that personality and behavior are "changeable."

Attribution Theory

The way in which an individual analyzes behaviors and events is the basic component of attribution theory (Weiner, 1979). Attribution is linked to motivation and self-esteem. Attribution can also be tied to persistence. Weiner (1979) lists ability, effort, task difficulty, and luck as causes employed by individuals to explain success and failure. He describes attribution as "the search for understanding."

Weiner (1979) goes on to explore attribution in terms of three continuums in addition to the causes listed above. Locus of control, stability, and controllability are considered dimensions of causality (Weiner, 1979; Warring, 1991). Schultz and Pomerantz (1976) state, "Locus of control mediates the effects of achievement 
motivation on achievement behavior by distinguishing those high need achievers who find achievement activities attractive (internals) from those who do not (externals)" ( $p$. 38). Stability refers to changes over a period of time. Doctor (2004) points out that "ability and task difficulty are stable because they cannot be easily changed or manipulated. On the other hand, effort and luck are unstable because students' amount of luck or effort is very likely to change from one situation to the next" (p. 6). Weiner (1979) goes on to show that controllability evaluates controllable causes such as effort, verses uncontrollable causes, like luck.

In the academic setting, attribution is represented in terms of success, failure, and satisfaction. Students tend to ask "Why did I fail" or "Why did I succeed". Failure leads to more inquiry on the part of the student than success. Students tend to search for further explanation when they fail or suffer rejection verses students who succeed or find acceptance. This occurs as a result of "why" questions that follow failure. For example, students will ask "Why did Mary do better than me on the test" or "Why did I fail the Math test" (p. 4). In addition, unforeseen events also garner more attention than expected events (Weiner, 1979). Nathawat, Singh, and Singh (1997) state, "Expected outcomes tend to be attributed to internal factors more often than unexpected outcomes do" (p. 56). The unexpected outcomes are usually attributed to external factors which leave an individual searching for cause.

A pattern of attribution is demonstrated depending on outcomes. Motivational elucidations, the explanation for what motivates an individual, demonstrate internal attributions for positive, expected outcomes more often than unexpected outcomes. The need to determine an explanation is due to individual effort to naturally preserve self 
esteem. However, negative, unexpected outcomes tend to yield the opposite result, leading to external attributions (Nathawat, Singh, \& Singh, 1997). For example, if students study diligently and successfully pass a test, they tend to attribute their success to an internal source (effort, ability). If students study diligently and unexpectedly fail a test, they tend to attribute the failure to an external source (the teacher, bad luck, poorly constructed exam).

A student's perceived control (or lack of) has been shown to impact academic success which then impacts retention (Perry \& Penner, 1990). Loss of control has a negative impact on achievement and motivation. The use of attribution retraining in altering a student's perceived control has demonstrated much promise in improving a student's perception of their own effort and control (Perry \& Penner, 1990).

\section{Attribution Retraining}

Attribution retraining (AR) is a remediation strategy which promotes controllable perceptions and alters causal attributions. In other words, managing thought processes and the way in which an individual answers "why" questions about a variety of situations (Hall et al., 2004; Perry \& Penner, 1990). By promoting controllable explanations, students can attribute their failures to facets which can be altered for future success, such as effort and study skills. The goal of attribution retraining is to promote the adoption of "controllable and unstable explanations for academic failure" among students (Hall et al., 2004, p. 362).

In modifying attributes, motivation increases as students "try harder" knowing success is within their control. Hall et al. (2004) found that attributional retraining improved course grades. These results support other research which also reports 
higher individual grade point averages (GPAs) among students who received attributional retraining (Hall et al., 2004; Wilson \& Linville, 1985).

Attributional retraining can take several forms. The type of intervention chosen is dependent on the setting and attributes being sought for change. In the past, researchers have utilized the following AR interventions: videotapes, expressive instruction, effort feedback, and elaborative learning (Hall et al., 2004; Perry \& Penner, 1990; Wilson \& Linville, 1982). Wilson and Linville (1982) studied the use of videotape intervention with college freshmen. They measured grade point average and used sample questions from a study book for the Graduate Record Examination as their measures. The students answered six multiple choice questions after reading a brief paragraph. They found an increase in grade point average and higher performance levels on the Graduate Record Examination questions as a result of the intervention. Perry and Penner (1990) found that highly expressive instructors, along with attribution retraining, significantly improved the performance of those students who were considered to have external locus of control. Hall and associates (2004) studied elaborative learning as an attribution retraining intervention. Elaborative learning, also known as deep processing, is demonstrated by summarizing materials from a course, paraphrasing, and using examples. This study supports previous research in finding a correlation between attribution retraining and improving "perceptions of control" in college students. More recently, computer based attributional retraining has been tested as an intervention (Horan et al., 2000). John Horan and graduate student Amy Tompkins-Bjorkman implemented the use of a multimedia software program called Just Think It to change attributions. 


\section{Conclusion}

Community colleges continue to explore options to improve academic achievement, course persistence, and retention to serve a unique population of students. Institutional changes have demonstrated modest gains in this area. Research indicates that personal characteristics play a considerable role in the success or failure of a student. These issues are exacerbated in the distance learning environment. Distance learning students often have to overcome concerns with the course format in addition to personal issues. Concerns often center upon self regulation, locus of control, and attributions. Research in these areas helps to provide further explanation as to why some students succeed while others fail. Attribution retraining can alter locus of control which in turn can impact academic achievement and retention. Shifting student's attributions through intervention may be the cost-effective way to meet the needs of the individual student and benefit the community college by improving academic achievement and course retention. 


\section{CHAPTER THREE}

\section{METHOD}

This chapter describes the methods used in the study. A description of participants and course, data collection procedures, instrumentation, interventions, research design, and limitations are examined.

The focus of this study examined attribution retraining in a distance education environment. Measures included locus of control, academic achievement (final course grades), and course retention. The study sought to determine the existence of a relationship between attribution retraining and an increase in internal locus of control. Locus of control scores, final course grades, and course retention statistics were measured against a control group where no intervention was employed to denote any differences. The intervention consisted of an interactive, multi-media program. The intervention treatment was offered to the control group following the completion of the study. The study sought to answer the following research questions:

1: Did attribution retraining (an interactive multi-media intervention) implemented in Internet courses change a students' internal locus of control?

2: Did attribution retraining (an interactive multi-media intervention) implemented in Internet courses demonstrate a significant difference in achievement (final course grades)?

3: Did attribution retraining (an interactive multi-media intervention) implemented in Internet courses demonstrate a change in course retention? 


\section{Participants and Course}

The participants of this study were students enrolled in the four distance learning sections of EDU202, Instructional Technology, during the 2007 summer and fall semesters at the Community College of Allegheny County (CCAC). The summer semester began on May 21, 2007 and was 10 weeks in duration. The fall semester began September 4, 2007 and was 14 weeks in duration. This course was offered through Blackboard Learning Systems, an online courseware program. The course was offered in an asynchronous format, meaning there was no real time interaction. All communication took place through email and discussion boards. The course cap for each section was 25 . Two sections in the summer and two sections offered in the fall potentially could have yielded a subject pool of 100 students. Ninety-eight students registered. Students were identified through course rosters generated from the office of the registrar and posted on CCAC's online information system, CCAC Central. A final roster of students was added to the course sites through the distance learning office. Students had one week to drop or add the course and had the opportunity to withdraw from the course through June 7, 2007 in the summer session and October 29, 2007 in the fall session.

Participants enrolled in the distance learning sections of EDU202 included both full-time and part-time students. All students were admitted to CCAC through the admissions office. While some were strictly CCAC students (51\%), others were students enrolled at 4 year colleges or universities (12\%). In addition, students returning to college to obtain a second degree were enrolled in the course (24\%). Enrolled students exhibited a wide range of demographics including gender ( $80 \%$ female and $20 \%$ male), 
age, class rank, GPA (grade point average), and employment status. The average age was 27 years old. The average GPA was 3.3 and $41 \%$ of the students were employed full-time. Though the class was online, all of the students enrolled were residents of Pennsylvania, and more specifically Allegheny County, where tuition was less than it would be for students residing outside of the county.

Students enrolled in EDU202, Instructional Technology, are pursuing a degree in education. Majors range from Elementary, Secondary, and Special Education to Liberal Arts. The course is a social science course that is typically only required in the field of education. In rare instances a student may take the course as a social science elective for another major. The course can also be used for Act 48 credits therefore, certified teachers may also be enrolled.

EDU202, Instructional Technology, is a course which explores various types of technologies and integration strategies suitable for the K-12 classroom. Objectives for the course include the following: Define and apply technology integration theories, utilize instructional resource material and technology, locate and analyze instructional resources, and design media for presentation and instructional purposes. Students create two large projects incorporating several types of instructional technologies. Students also critique instructional websites on a regular basis. A copy of the course outline can be found in Appendix A.

The instructor for the course was also the researcher in this study. She is a fulltime associate professor and has been teaching in higher education for eight years and teaching online courses for seven years. She has been employed at the Community College of Allegheny County for three years. She has taught nine sections of EDU202, 
Instructional Technology, in both the online and face-to-face formats in previous semesters. The instructor is experienced in the field of distance learning and has studied distance education. The course has gone through several edits in order to continually improve content and delivery methods.

A WVU Institutional Review Board (IRB) guideline for the protection of human research subjects was completed prior to any requests for student participation. Students had informed consent as to the research taking place (see Appendix B). In addition, approval for the research was obtained in writing from the vice president of academic affairs at the Community College of Allegheny County.

\section{Data Collection}

All data for this study was collected through the online Blackboard courseware site for EDU202 Instructional Technology and reported in the Community College of Allegheny County's data administration system, CCAC Central. Following the drop/add period, in week two of the course (May 28, 2007 to June 4, 2007 for the summer session) and (September 11, 2007 to September 18, 2007 for the fall session), participants were informed of the impending research study via Course Announcements. Participation in all aspects of the research study was voluntary. Participants were instructed as to the procedures of the research and as to where the research tools were located. A demographic survey and Rotter's Locus of Control Scale (LOC), located in Appendix C, were posted under the link Course Research. Each tool was designed to gather results electronically to the Blackboard site. Participants were given one week to complete the questionnaire and LOC Scale after which both were 
removed from the site. Students were given informed consent and the option to opt out of completing the LOC Scale and demographic survey with no penalty.

Following the implementation of attribution retraining intervention in three of the four sections (summer and fall), Rotter's Locus of Control Scale was posted again for completion at the end of the course for all four sections. Students were informed of this via Course Announcements.

The demographic survey and Rotter's Locus of Control Scale were administered to the control group though no treatment was assigned. With a pretest/posttest design, each group may have become sensitized to the pretest. The use of the pretest could give students cues that may have skewed the posttest results. In addition, a period of several weeks elapsed between the pretest and posttest which may have allowed the student to become acclimated to the course and grow as an individual which could have also affected the posttest results. By assigning to the control group, it preserved internal validity as all groups were given the same opportunity for maturity from pretest to posttest (Dawson, 1997).

Final grades were collected and analyzed one week after the end of the course, as were course retention statistics. This information was made available through CCAC's electronic course tracking system, known as CCAC Central.

\section{Instrumentation}

Data was collected for this study using the following tools: a demographic questionnaire, Rotter's Locus of Control Scale, final course grades, and course retention statistics.

Demographic Questionnaire 
A questionnaire was designed to collect general demographic information on each participant. Categories included: age, gender, race, employment status, marital status, class rank (freshman, sophomore, junior, senior, graduated student, returning student). In addition, information was gathered on the participant's current academic enrollment: full time, part time, CCAC student, other college or university student, or classroom teacher seeking Act 48 hours. Locus of control has in the past been correlated to demographic characteristics (Neill, 2005). Gender plays a role with males tending to be more internal than females. Age also is a factor in internal verses external locus of control. Older people become more internal. In addition, employees in higher end jobs demonstrate a more internal locus of control (Neill, 2005). The demographic survey was used to assist in identifying variables which may have impacted locus of control results.

Rotter's Locus of Control Scale

Rotter's Locus of Control Scale is a 29 question, forced answer survey (Rotter, 1966). Participants had to choose between one of two responses. Each response represents either internal or external reinforcement beliefs. Internal locus of control refers to an individual attributing success or failure to personal control. External locus of control refers to an individual attributing success or failure to something outside of their control. Depending on the response to Rotter's Locus of Control Scale, an inclination towards one or the other was determined. Locus of control is considered to be a learned response stemming from family and environment (Neill, 2005). Therefore, changes in circumstance and attribution retraining can alter locus of control measures. Hence, Rotter's Locus of Control Scale was utilized in a pretest/posttest comparison. Lange and 
Tiggemann (1980) found the Internal-External (I-E) scale had a test-retest reliability of .61. Rotter found test-retest reliability to range from .49 to .83 in a variety of samples (Domino \& Domino, 2006). Rotter's Locus of Control Scale is shown in Appendix C. Final Course Grades

Grades were determined in the course with a variety of assignments and projects. Assignments ranged in point value from 25 points for weekly assignments to 100 points for the two major projects, along with the final exam. No assignments in the course were weighted and no grading curve was used. The total number of points for the course was 545. Grades were calculated using a percentage point system. Letter grades were determined by applying a ten percent scale to the total points. Therefore, ten percent was subtracted from the point total to determine the cut-off score for an " $A$ " (545-491), twenty percent was deducted from the point total to determine a "B" (490436) and so on.

\section{Course Retention Statistics}

Course retention refers to the number of students who successfully completed the course to the final week with a passing grade. Students who dropped the course, withdrew from the course, or failed the course were not considered to be retained. Course retention statistics were determined at the end of course through the examination of the course roster from the beginning of the course until the end and with final course grades.

\section{Intervention}

One intervention was used in this study. The treatment was an interactive multimedia program designed to provide attribution retraining strategies. 
The interactive, multimedia program titled, Just Think It: Internet-Based Attribution Retraining for Academic Motivation and Performance, was implemented in three of five sections of EDU202 Instructional Technology. This program was designed by Amy Tompkins-Bjorkman and John Horan (Horan et al., 2000). The purpose of the program was to enhance academic motivation through attribution retraining. The ultimate goal was to replace "maladaptive causal attributions" with "functional attributions" (Horan et al., 2000). The program consists of eight animated counselors who advised students by asking a series of attribution questions, providing explanation for responses, and then elaborating on the particular attribution. Students began by choosing two counselors, one male and one female. The counselor asked the student a "do you ever feel this way" type of question. The student then chose one of four responses: "usually, sometimes, never, tell me more." The student was then taken to a screen that asked a "does that make sense" type of question and the counselors explained the attribution behavior. The student then selected from: "I don't get it, I kinda get it, I understand, or tell me more." The final screen in the series entailed a "click on the button that best describes your feelings now" and the student selected from: "sounds good to me, let's move on, I don't get it, let's run through it again, or I don't buy that but let's move on." Based on their choices, students may have been re-cycled through the previous selections or moved on to a new series of: "Do you ever feel this way, does that make sense," and clicked on a button that best described their feelings, questions, and explanations. Screen shots of the program are displayed in Appendix D. The program consisted of two parts and students were asked to complete both sections. Students were then asked to evaluate the program using a multimedia evaluation form. 


\section{Research Design}

The study used a pretest-posttest control group design. The format was quasiexperimental as random assignment of subjects was limited to course sections. Four sections of the distance learning course EDU202 Instructional Technology represented the two groups, treatment and control. Each section was given the Rotter's Locus of Control Scale as shown in Appendix C, which measured internal verses external locus of control, during the second week of class as a pretest. The pretest was used as a covariate to compensate for initial differences among sections. Three sections of participants received an interactive multi-media intervention, and the one section received no intervention. Rotter's Locus of Control Scale, as shown in Appendix C, was administered in the last week of the class and posttest results were compared for all sections to determine any change. The goal of attribution retraining intervention was to raise the internal locus of control and thus demonstrate a change in a subject's attributions. Results were then compared among groups to determine significant difference. In addition, final course grades and course retention statistics were compared among groups to note significant differences. Demographic information was gathered to account for external variables which may have impacted locus of control scores.

Table 1 demonstrates the research design format. 
Table 1

Summary of Research Design

\begin{tabular}{cccccc}
\hline $\begin{array}{c}\text { Randomly } \\
\text { Assigned Course } \\
\text { Sections }\end{array}$ & $\begin{array}{c}\text { Pretest } \\
\text { Demographic } \\
\text { Survey }\end{array}$ & Treatment & Posttest & $\begin{array}{c}\text { Final } \\
\text { Grades }\end{array}$ & $\begin{array}{c}\text { Course } \\
\text { Retention }\end{array}$ \\
\hline $\begin{array}{c}\text { Experimental } \\
\text { Group \#1 }\end{array}$ & $\mathrm{T}_{1}$ & $\mathrm{X}_{\mathrm{a}}$ & $\mathrm{T}_{2}$ & $\mathrm{~T}_{3}$ & $\mathrm{~T}_{4}$ \\
Control Group & $\mathrm{T}_{1}$ & & $\mathrm{~T}_{2}$ & $\mathrm{~T}_{3}$ & $\mathrm{~T}_{4}$ \\
& & & & &
\end{tabular}

Note. $\mathrm{T}=$ data; $\mathrm{X}=$ intervention.

Research questions for this study were addressed in the following manner:

Research Question 1: Impact of Attribution Retraining on Internal Locus of Control

The data source for Research Question 1 was Rotter's Locus of Control Scale, located in Appendix C. It was administered to all four sections of participants at the beginning of the semester and the end of the semester in a pretest-posttest control group design. Pretest results were a covariate demonstrating differences among groups. Posttest results were measured and compared using a repeated measures ttest procedure analyzing significance in both the treatment and the control group. Research Question 2: Impact of Attribution Retraining on Final Course Grades

The data source for Research Question 2 was final grades for the EDU202, Instructional Technology course, as reported to the Community College of Allegheny County electronic grade reporting system, CCAC Central. Grades were determined using a point system for the course. A ten percent scale was implemented taking the total points and subtracting ten percent to get the cutoff scores for each letter grade, A 
through F. The mean and standard deviation of points were compared between the treatment and control groups.

Research Question 3: Impact of Attribution Retraining on Course Retention

The data source for Research Question 3 was course retention statistics as reported to the Community College of Allegheny County electronic data reporting system, CCAC Central. Course retention refers to the number of students enrolled in each credit course after the drop/add and withdraw periods and the number of students who pass the course with an A-D grade at the end of the term, according to CCAC's definition of a passing grade. Retention statistics for the four groups were compared. A frequency distribution for retention was examined among the four sections for the following: students who dropped, students who withdrew, students who failed, and students who completed the course with a passing grade. Results were displayed in a frequency table. Numerous studies have demonstrated a link between retention and internal locus of control (Dille \& Mezack, 1991;Morris, Wu, \& Finnegan, 2005; Parker, 1999). While many factors impact course retention, this study attempted to demonstrate a correlation to the locus of control component.

Table 2 provides a summary of research questions, data sources, and analysis procedures. 
Table 2

Research Questions, Data Sources, and Analysis Procedures

\begin{tabular}{|c|c|c|}
\hline Research Question & Data Source & Analysis \\
\hline $\begin{array}{l}\text { 1: Does attribution retraining (interactive multi- } \\
\text { media intervention or no intervention), } \\
\text { implemented in Internet courses, change a } \\
\text { student's internal locus of control? }\end{array}$ & $\begin{array}{l}\text { Rotter's Locus } \\
\text { of Control Scale } \\
\text { Demographics }\end{array}$ & $\begin{array}{l}\text { Covariate } \\
\text { Repeated } \\
\text { measures t- } \\
\text { test }\end{array}$ \\
\hline $\begin{array}{l}\text { 2: Does attribution retraining (interactive multi- } \\
\text { media intervention or no intervention) } \\
\text { implemented in Internet courses demonstrate } \\
\text { a significant difference in achievement (final } \\
\text { course grades)? }\end{array}$ & $\begin{array}{l}\text { Final course } \\
\text { grades } \\
\text { CCAC } \\
\text { Central } \\
\text { Grade } \\
\text { Reporting } \\
\text { System }\end{array}$ & $\begin{array}{l}\text { Frequency } \\
\text { Distribution } \\
\text { Mean and } \\
\text { standard } \\
\text { deviation }\end{array}$ \\
\hline $\begin{array}{l}\text { 3: Does attribution retraining (interactive multi- } \\
\text { media intervention or no intervention) } \\
\text { implemented in Internet courses demonstrate } \\
\text { a change in course retention? }\end{array}$ & $\begin{array}{l}\text { Course } \\
\text { rosters } \\
\text { CCAC } \\
\text { Central } \\
\text { Data } \\
\text { Reporting } \\
\text { System }\end{array}$ & $\begin{array}{l}\text { Frequency } \\
\text { Distribution }\end{array}$ \\
\hline
\end{tabular}

\section{Limitations}

The limitations of this study are:

1. The quasi-experimental design and random assignment of subject according to course section makes the assumption that groups are equivalent.

2. Results of the pretest-posttest control group can be confounded by the pretest. Students who are pretested may be more responsive to the intervention or may learn from the pre-test which could alter posttest results.

3. Changes to an individual's locus of control can be circumstantial and environmental and therefore one cannot fully attribute changes to the given intervention. 
4. The sample was one of convenience.

5. The research took place with students enrolled at the Community College of Allegheny County and may not be generalizable to other community colleges.

6. The researcher was also the instructor for the three sections of students in the study, which may have resulted in unintentional bias in data collection and analysis.

7. The time frame of the study was limited to two semesters.

8. Summer and fall students were assumed to be similar, although demographics differed. 


\section{CHAPTER FOUR}

\section{FINDINGS}

\section{Sample}

The data was collected from participants through the survey tool on the Blackboard course management site for each section of the online course EDU202 Instructional Technology at the Community College of Allegheny County. Four sections of the course were surveyed in the summer and fall 2007 semesters. The sample included 71 students who participated in the research and completed the demographic, pre- and posttest surveys. Nine students did not complete the surveys and were not included in the findings. Additional data was gathered through CCAC's student tracking program, CCAC Central, which reported enrollment statistics and final grades.

Of the 71 students surveyed, the average age was 27.4 . Nineteen percent of the students were male and $81 \%$ of the students were female. Fifty-two percent of the students were CCAC students only, while $12 \%$ were enrolled full-time at a different college, and $24 \%$ were graduate students. Sixty percent of the students considered themselves to be full-time (registering for 12 credits or more per semester according to CCAC's definition of full-time status), and $40 \%$ indicated they were part-time students, registering for less than 12 credits per semester. Nearly half of the students, $51 \%$, received some type of financial aid. The average grade point average of the sample was 3.3. Forty-one percent of the students noted they were employed full-time, and $45 \%$ stated they were employed part-time, with $14 \%$ being unemployed. It should be noted there were marked differences between the summer sections and those offered in the fall. Students in the two summer sessions tended to be older and more educated 
than those taking the course in the fall. They also tended to have higher levels of education with $37.5 \%$ of the summer students indicating they were graduate students as opposed to $9 \%$ in fall semester. Summer students were split to make up the control and treatment groups in an attempt to account for the differences in demographics. The control group consisted of strictly those students enrolled in the summer semester.

The average number of college credits completed by the sample was 83.6 . The students, on average, had completed 2.75 online courses prior to registering for this course. Table 3 provides a detailed report of demographic information for the sample.

Table 3

Demographic Information of Sample

\begin{tabular}{|c|c|c|c|c|}
\hline Category & & Mean & Summer & Fall \\
\hline Age & & 27.46 & 29.30 & 25.63 \\
\hline \multicolumn{5}{|l|}{ Gender } \\
\hline & Male & 19.40 & 15.20 & 23.60 \\
\hline & Female & 80.57 & 84.75 & 76.40 \\
\hline \multicolumn{5}{|c|}{ Educational Status } \\
\hline & Full-time & 60.05 & 58.30 & 41.65 \\
\hline & Part-time & 39.92 & 61.80 & 38.20 \\
\hline \multicolumn{5}{|c|}{ Current Education Level } \\
\hline & Associate & 51.02 & 29.85 & 72.20 \\
\hline & Bachelor & 12.30 & 23.00 & 5.95 \\
\hline & Graduate & 24.02 & 36.85 & 11.20 \\
\hline & Other & 12.65 & 17.10 & 8.20 \\
\hline
\end{tabular}


Average GPA

Employment Status

$\begin{array}{cccc}\text { Full-time } & 41.00 & 44.45 & 38.20 \\ \text { Part-time } & 45.00 & 41.65 & 47.60 \\ \text { Unemployed } & 14.00 & 13.85 & 14.25 \\ \text { College Credits Completed } & 83.60 & 93.95 & 73.25 \\ \text { Online Courses Completed } & 2.75 & 2.30 & 3.20\end{array}$

Results

Research Question 1: Does attribution retraining (an interactive multi-media intervention) implemented in Internet courses change a student's internal locus of control?

All sections of the online course EDU202 Instructional Technology completed a pre and posttest; Rotter's Locus of Control survey. The pretest determined a baseline report of the student's locus of control score indicating internal or external. The pretest was administered in week two of the semester. Three sections (treatment group) were shown the Just Think It multimedia intervention and one section (control group) was not. The intervention was administered online through the Blackboard assignment tool. The treatment group received the intervention in week four of the semester. The treatment group was directed to the Just Think It website. Students were asked to go through the entire two-part program. To make certain the treatment group thoroughly reviewed the Just Think It program, they were asked to summarize and evaluate it using directions 
from an assignment sheet and a pre-designed multimedia software evaluation form (Appendix E). The treatment group was then asked to upload the summaries and evaluations into the Blackboard assignment window for review.

The posttest survey was administered and the change score between pre and posttest measurement of the dependent criterion variable of locus of control score was analyzed using a repeated measures t-test. The posttest was administered to both the control and treatment groups in week nine of the semester. The repeated measures ttest was used to measure the change between pre and posttest scores for the treatment group only. A repeated measures t-test was not used to compare the posttest results of the treatment and control groups. This strategy was employed, whereas the student served as his or her own control group, allowing for a larger sample size for the treatment group ( $n=56)$ and the control group $(n=15)$. The repeated measures tend to require fewer subjects because each subject is measured in both pre and posttest conditions. The result was a more powerful test because it isolated individual groups and reduced problems caused by individual differences. Table 4 reports the frequency count for the treatment group in terms of internal verses external placement on Rotter's Locus of Control Scale. Pretest results showed that 30 students scored in the internal range on the LOC Scale while 26 students scored in the external range. Posttest results indicated that 35 students scored in the internal range while 30 students scored in the external range. The LOC Scale scores one point for certain responses to each question in the 29-point survey. Those who scored 11 points or fewer are considered internal and those who score 12 points or more are considered external (see Appendix C). 
Table 4

Locus of Control Pretest and Posttest Treatment Group

\begin{tabular}{llll} 
& $N$ & Internal & External \\
\hline Pretest & 56 & 30 & 26 \\
Posttest & 56 & 35 & 21 \\
\hline
\end{tabular}

Table 5 records the frequency count for the control group in terms of internal verses external placement on Rotter's Locus of Control Scale. Results show that seven out of 15 students scored in the internal range on the pretest and eight students scored in the external range. The posttest shows a slight shift with eight students scoring in the internal LOC range and seven students scoring in the external range.

Table 5

Locus of Control Pretest and Posttest Control Group

\begin{tabular}{llll} 
& $N$ & Internal & External \\
\hline Pretest & 15 & 7 & 8 \\
Posttest & 15 & 8 & 7 \\
\hline
\end{tabular}

A repeated measures t-test was calculated using SPSS software to determine if there was a significant difference among those in the treatment group, who viewed the intervention, in regard to locus of control score from the pre/posttest assessments. The treatment group was pretested, then viewed the intervention, and then was given a posttest to determine a change in locus of control score. The treatment group showed no significant change from pre to posttest assessment in regard to internal verses external locus of control. The two-tailed, repeated measures t-test revealed $t(55)=1.33$, 
$p>.05$, indicating no significant difference. Table 6 illustrates the repeated measures ttest for the treatment group.

Table 6

Repeated Measures t-test Treatment Group

\begin{tabular}{lcccccccc}
\hline & Mean & $\begin{array}{c}\text { Std } \\
\text { Deviation }\end{array}$ & \multirow{2}{*}{$\begin{array}{c}\text { Std. Error } \\
\text { Mean }\end{array}$} & \multicolumn{2}{c}{$\begin{array}{c}\text { 95\%Confidence } \\
\text { Interval } \\
\text { Lower }\end{array}$} & Upper & df & Sig. \\
$(2-$ & tailed) \\
\hline $\begin{array}{l}\text { Pair 1 } \\
\text { Pre-Post }\end{array}$ & 1.07 & 6.02 & .80 & -.54 & 2.68 & 1.33 & 55 & .188 \\
\hline
\end{tabular}

A repeated measures t-test was calculated using SPSS software to determine if there was a significant difference among those in the control group, who did not view the intervention, in regard to locus of control score from the pre/posttest assessments. The repeated measures t-test was used to measure the change between pre and posttest scores for the control group only and did not compare treatment and control groups. If results of the repeated measure t-test had been significant for the treatment group, a t-test would have been used to compare the treatment and control groups in order to verify that no external influences existed. This was not necessary as the repeated measures t-test for the treatment group was not significant. The two-tailed, repeated measures t-test for the control group revealed $t(14)=0.15, p>.05$, indicating no significant difference. Table 7 illustrates the repeated measures t-test for the control group. 
Table 7

Repeated Measures t-test Control Group

\begin{tabular}{lcccccccc}
\hline & Mean & $\begin{array}{c}\text { Std } \\
\text { Deviation }\end{array}$ & $\begin{array}{c}\text { Std. Error } \\
\text { Mean }\end{array}$ & $\begin{array}{c}\text { 95\%Confidence } \\
\text { Interval } \\
\text { Lower }\end{array}$ & Upper & df & $\begin{array}{c}\text { Sig. } \\
(2- \\
\text { tailed) }\end{array}$ \\
\hline $\begin{array}{l}\text { Pair 1 } \\
\text { Pre-Post }\end{array}$ & .20 & 5.15 & 1.33 & -2.65 & 3.05 & .15 & 14 & .883 \\
\hline
\end{tabular}

Locus of control scores did not significantly change for the treatment group with the attribution retraining in looking at pre and posttest results. The attribution retraining did not change the scores in a statistically significant way.

Research Question 2: Does attribution retraining (an interactive multi-media intervention) implemented in Internet courses demonstrate a significant difference in achievement (final course grades)?

The treatment group consisted of 56 students in three sections of EDU202 Instructional Technology. Those who dropped, withdrew or chose not to participate in the research were not included in the mean score for average grade. The treatment group average grade was Mean $=3.13$ of a four-point scale. A four-point grading scale assigns grade points as follows: $A=4.0, B=3.0, C=2.0, D=1.0$, and $F=0$. The average grade was slightly higher than a B. The control group consisted of 15 students in one section of EDU202 Instructional Technology. The control group average grade was Mean $=3.26$ out of a four-point scale. Table 8 presents the frequency count for grades in both the treatment and control groups. 
Table 8

Frequency Count of Grades in Treatment and Control Groups

\begin{tabular}{llllll}
\hline Grades & $\mathrm{A}(4.0)$ & $\mathrm{B}(3.0)$ & $\mathrm{C}(2.0)$ & $\mathrm{D}(1.0)$ & $\mathrm{F}(0)$ \\
\hline Treatment & 31 & 15 & 3 & 0 & 7 \\
Control & 9 & 3 & 2 & 0 & 1 \\
\hline
\end{tabular}

The control group average grade was slightly higher than the treatment group. Table 9 presents the $N$, Mean, and Standard Deviation of grades for both the treatment and control groups indicating the intervention had little impact on the course grades. It appeared that no difference was found in the average grades for the treatment group, who received the intervention, and the control group, who did not. Attribution retraining did not significantly impact achievement.

Table 9

Average Grade of Entire Sample

\begin{tabular}{lccc}
\hline Groups & $N$ & $M$ & $S D$ \\
\hline Treatment & 56 & 3.13 & 1.32 \\
Control & 15 & 3.26 & 1.26 \\
\hline
\end{tabular}

Research Question 3: Does attribution retraining (an interactive multi-media intervention) implemented in Internet courses demonstrate a change in course retention?

Four sections of the online course EDU202 Instructional Technology made up the sample. Two sections were offered in the summer 2007 semester and two in the fall 
2007 semester. Each section had an enrollment cap of 25 students with the potential for 100 students in the sample. Enrollment showed 98 students registered for the course, distributed through the four sections. Of the 98 students enrolled, 71 students participated in the research until the end of the course, a $73 \%$ participation rate.

The treatment group began with 64 students who completed the pretest and 60 students who received the multimedia intervention, Just Think It. From the 64 students, four students dropped the course in the first two weeks and four students withdrew from the course by week ten. Seven students failed the course with an F grade. Seventyseven percent of the students enrolled in the sections where intervention was provided successfully completed the course with a $\mathrm{C}$ or higher grade.

The control group began with 23 students who completed the pretest. The multimedia intervention, Just Think It, was not offered to this group. Seven students in this group dropped the course within the first two weeks. One additional student withdrew from the course by week 10. One student failed the course with an F grade. The retention rate for the control group was $65 \%$. Table 10 illustrates the course completion for both the treatment and control group. Attribution retraining did have an impact on retention rates. The treatment group, who received the intervention, had a higher retention rate than the control group, who did not receive the intervention.

Table 10

Retention Distribution

\begin{tabular}{lrrrrrr}
\hline Group & Pretested & Dropped & Withdrew & Persisted & Failed & Completed \\
\hline Treatment & 64 & 4 & 4 & 56 & 7 & 49 \\
Control & 23 & 7 & 1 & 15 & 1 & 14 \\
\hline
\end{tabular}


The treatment group had a better retention rate than the control group. Table 11 presents retention rates for both the treatment and control groups. The treatment group had 49 of 64 students complete the course with a retention rate of $77 \%$. The control group had 14 of 23 students complete the course with a retention rate of $61 \%$.

Table 11

Retention Rates

\begin{tabular}{lccc}
\hline Groups & Sample & Completed & Retention Percentage \\
\hline Treatment & 64 & 49 & $77 \%$ \\
Control & 23 & 14 & $61 \%$ \\
\hline
\end{tabular}

The retention rate for the treatment group in the course was higher than the average retention rate for CCAC. Though the college does not track individual course retention, it does report semester-to-semester retention. In 2005, the rate for term-toterm retention was $66.8 \%$ as cited by M.K. Quilan (personal communication, February 8, 2008, Learning Assessment Analyst, Office of Planning and Institutional Research at CCAC). 


\section{CHAPTER FIVE}

\section{DISCUSSION}

The purpose of this study was to determine the impact of attribution retraining in the form of interactive multimedia intervention on locus of control, course grades, and course retention for community college students enrolled in the distance learning course EDU202 Instructional Technology. Other types of attribution retraining studies have been done in a traditional classroom environment and other locus of control studies have been done in the online environment but to date no research has been done to examine the impact of attribution retraining on locus of control in an online learning environment.

\section{Summary of the Study}

The research took place over the period of two semesters, summer 2007 and fall 2007, at the Community College of Allegheny County in Western Pennsylvania. Four sections of the online course EDU202 Instructional Technology were included; three sections were used for the treatment group and one was used at the control group. A total of 71 students made up the sample; 56 students in the treatment group and 15 students in the control group.

All students were given a demographic survey along with Rotter's Locus of Control survey in week 2 of the semester. The treatment group was assigned the task of reviewing and evaluating Just Think It, an interactive multimedia intervention, designed to retrain student's attributions to success and failure. The entire sample was given Rotter's Locus of Control survey again in order to garner any posttest changes as a result of intervention. Course grade averages and course retention statistics were 
compared after the course ended in an attempt to determine differences among the treatment and control groups.

Research question one, looking at the differences in pre and posttest scores for the treatment and control groups using Rotter's LOC Scale, showed no trend toward a significant difference. In the treatment group, the pretest showed 30 students had a score which indicated they possessed an internal locus of control, while 26 student's scores indicated they possessed an external locus of control. The posttest scores marked a change in the treatment group whereas 35 students scored in the internal range and 21 had a score indicating external locus of control. The control group pretest results indicated that seven students had an internal LOC score and eight students had an external score. The posttest scores showed a very slight change with eight students scoring in the internal range and seven students scoring in the external range. However, a clear distinction was made between treatment and control groups. Sixty three percent of the treatment group had an internal locus of control score while only $54 \%$ of the control group had an internal score. A larger sample could result in a shift toward significance.

Research question two examined the final grade averages of the treatment and control groups. Students in the treatment group, who received The Just Think It intervention, did not have a higher final grade average than the control group, who did not receive the intervention. In fact, the control group yielded a slightly higher final grade average than the treatment group. The average grade for the treatment group was 3.13. The average grade for students in the control group was 3.26. The difference in final grade averages might be explained by sample size and retention rates. The control 
group $(n=15)$ was much smaller than the treatment group $(n=56)$. In addition, the control group lost nearly $40 \%$ of its students through drops and withdrawals. In essence, many students were weeded out of the control group through attrition. The control group only had one student who failed the course; while the treatment group had seven students fail, bringing down the grade average significantly.

Research question three examined the course retention rates for the treatment and control groups. The treatment group retained $77 \%$ of the students who registered or added the course. The control group retained $61 \%$ of the students who registered or added the course. Retention rates were determined by reviewing the number of students who enrolled in the course and subtracting those who dropped or withdrew. The treatment group had an initial enrollment of 64 students. Four students dropped and four students withdrew. In addition, seven students completed the course but did not pass. The control group had an initial enrollment of 23 students. Seven students dropped the course and one student withdrew. One student completed the course but did not achieve a passing grade. The treatment group had a better retention rate than the control group, retaining $16 \%$ more students. The results demonstrated that the intervention may have impacted retention rates as every other aspect of the course was the same. Despite the difference in sample sizes, the treatment and control groups lost the same number of students through drops and withdrawals, eight. The incidence of the different retention rates, especially for the control group, can partially be attributed to normal attrition. The majority of attrition in the control group was due to drops which took place in the first two weeks of the semester. The intervention would have made no difference to this group, as they were not enrolled in the course long enough to receive 
the treatment. However, the treatment group had higher-than-average course retention rates which may be partially attributed to the intervention. In reviewing retention rates for the course in the year prior, the average retention was $73 \%$ for five sections of the course. The treatment group retained $4 \%$ more students than in previous semesters.

Recommendations and Additional Limitations

\section{Recommendations}

Attribution retraining can be an effective strategy for exacting change in attitude and motivation among college students. Face-to-face treatments have yielded positive findings which demonstrate effectiveness (Perry \& Penner, 1990). Additional research is needed to determine the impact of attribution retraining in the distance learning environment. Different forms of attribution retraining such as video, live, and animated are available for experimentation with the distance learning student. Doctor (2004) found that the mode of presentation (live verses video) demonstrated a significant difference when examining homework completion rates of a treatment and control group. Live presentation proved to be more effective. Researchers must overcome the limitations of the distance learning environment and utilize the strengths of the technology. The original development of an attribution retraining intervention specifically for the distance learning environment may prove more effective than a pre-made product. Along with the utilization of different types or original attribution retraining, it is recommended that future research also use different or additional measures such as self-efficacy and motivation surveys to determine the impact of attribution retraining in these areas. It is also recommended that additional attribution retraining intervention sessions be incorporated into the teaching and subsequent research in lieu of the single 
application. Researchers need to further look at the difference in attribution retraining intervention in a face-to-face environment verses a distance learning environment and measure for effectiveness. Also, rather than implement an intervention later in a students' college career, a more effective method may be to implement attribution retraining during the first semester in order to start students on the right foot in terms of attitude and the impact on academic achievement.

Recommendations for Community Colleges

Community colleges have unique retention challenges such as commuter students, transfer students, limited admissions guidelines, and diversity of population. In their 2004 ACT policy report, Lotkowski, Robbins, and Noeth reported several factors related to retention and academic achievement. "Academic self confidence" had a strong relationship to retention and GPA. "Achievement motivation" had a strong relationship to GPA. It is clear that community colleges need to consider non-academic factors when looking for ways to assist students. Tools like Rotter's Locus Control Scale can be used to further identify non-academic factors that relate to student academic success. Learning support services should consider a variety of attribution retraining methods to identify those that effectively help in shifting student's attributions and motivations. Distance Learning Centers should consider pre-screening distance learning students in order to identify the non-academic factors that have been proven to impact academic success. Opportunities for attribution retraining should be offered in a variety of formats; online, face-to-face, or video to accommodate for population diversity.

\section{Additional Limitations}


Some limitations in this study included a limited sample size, voluntary participation, limitations of the pre/posttest format, short duration of data collection, challenges inherent to the distance learning environment, and the use of a dated software intervention. In addition, extraneous factors that impact locus of control, grades, and retention could not be accounted for.

The sample size was limited by the course cap of 25 students per section. Only four sections of the course were offered during the time of data collection. Participation was voluntary and a sample of convenience was used. Only students enrolled in the online sections of the course EDU202 Instructional Technology were used. It was assumed and later confirmed through records in the CCAC Central Data Reporting system that the entire sample was composed of teacher education and teaching assistant students, along with a limited number of certified classroom teachers. Teacher education students were in a program of study that would lead to transfer and completion of a four-year degree and teacher certification. Teacher assistant students were in a program of study that would lead to a two-year degree completion and employment as a teacher's aide or paraprofessional. While the background, age, and college status of participants varied, the study is only generalizable to this group.

Data collection was limited to two semesters, summer and fall. Two sections of students were included in the summer semester of 2007, and two sections of students were included in the fall semester of 2007 . The semester duration varied from 10 to 14 weeks. The entire control group was enrolled in one section offered in the summer semester. The treatment group included both summer and fall students. A longer 
duration of study, along with inclusion of additional sections of students, would have provided a larger sample and may have yielded more significant results.

The online delivery method of the course, along with the online delivery method of the intervention, proved to be a challenge. It was difficult for the researcher to truly determine if students thoroughly reviewed the intervention, Just Think It. Students were asked to summarize and evaluate the intervention to account for this limitation. Unfortunately, time on task, effort, and focus cannot be determined with the distance learning delivery method. Student summaries varied in length and detail from one short paragraph to two full typed pages.

As technology quickly advances and despite the relative novelty of the use of avatars, the Just Think It intervention was considered to be somewhat antiquated by the students. The avatars were referred to as "cartoon-like" and students expressed disappointment with the selection of counselors. The sample also articulated frustration over the repetition of the program and felt the content was condescending at times. Student summaries included opinions such as "When the student logs on to the website they are given an option to choose two counselors. The choices are between genders and are ethnically and diverse. Even though stated the "graphics have greatly improved" there is something left to be desired from the stereotypical "peer" counselors." On the flip side another student stated, "Answering honestly to these questions gave me a better understanding of my successes and failures. As I mentioned earlier, the content in both of these exercises were very similar, but also very effective." The student responses fell somewhere within the range of being insulted by the elementary nature of the intervention to stating that the program made them rethink the way they approached 
coursework. With advances in technology such as Second Life, by comparison, the avatars in Just Think It lacked dimension. Second life is a modern 3-D virtual world. It was founded in 2003 by Linden Research and offers live custom avatars verses the preset avatars in Just Think It (Second Life, 2008).

The pre/posttest design using locus of control scores used the same instrument for both measures. The survey included 29 items which students had to complete twice during the semester. In addition, there are some inherent limitations to a pre/ posttest design. One limitation being "response shift bias", or gaining a better understanding of the concepts in order to respond more accurately to the questions without actually shifting beliefs (Klatt \& Taylor-Powell, 2005).

Assumptions about final grade averages and course retention must be viewed with caution. Many factors can impact both measures. Tsai and Perry (1975) found no fewer than nine variables can impact grades. Gender, personal aspiration, program of study, and demographic location were included. Hall (2005) cited age, race, and college major as factors that also impacted grades and GPAs. A one-shot intervention cannot necessarily account for these factors. Retention rates are also precarious and influenced by many variables as well. Tinto (1998) cites academic difficulty, personal commitments, and finances as just some of the reasons why retention rates vary. Again, a single intervention could not overcome these factors.

\section{Suggestions for Future Research}

Research in the area of attribution retraining in a distance education environment is limited. Little or no research has been done to date and more studies are needed. Future research could account for several limitations listed in the previous section. 
Suggestions include expansion of the sample, improved and varied intervention treatment, and long range data collection.

The present study was limited to a sample of convenience, which included students enrolled in a Community College of Allegheny County distance learning course, EDU202 Instructional Technology. Size was limited by course caps and section offerings. Additional research expanding the sample to other courses as well as other community colleges, along with the inclusion of four year colleges, would eliminate the limitation of a convenience sample and prove to be more generalizable.

Future research needs to account for the challenges presented in a distance learning environment and improvements to the multimedia intervention made. A more technologically advanced intervention with improved tracking and interactivity would allow for greater control and access for the researcher and sample alike. The creation of more life like avatars might improve the student's perception of the treatment.

Long term measures of locus of control, GPA, and retention rates would provide a more detailed report on the impact of the attribution retraining intervention. In addition, a closer look at locus of control scales and accounting for extremes in scores would provide additional data. More closely linking demographics to data collection would also provide additional insight. Expanding the time frame of the study to a year, or even the entire duration of the student's college experience, would provide a long range perspective and measurement of outcomes. The addition of duration would allow researchers to measure overall GPA and program retention rates, rather than those limited to one course. 
Despite the results of this study, having no significant difference between pre and posttest locus of control scores, a substantial amount of research has been done correlating LOC to academic success and persistence (Parker, 2003; Stone, 1992). Much of this research verifies that LOC is a changeable construct and warrants continued research to further help students succeed academically. Strategies for implementing a change from external locus of control to internal locus of control are varied. While LOC may be changeable and statistically relevant, this study found the attribution retraining method is a key factor for change. Future research should explore different types of attribution retraining to identify the most effective in creating this change in LOC.

\section{Conclusion}

Attribution retraining in the form of a multimedia, interactive program called Just Think It did reveal a slight shift in regard to locus of control scores, though not statistically significant. A posttest demonstrated several students shifted from an external locus of control score to an internal score. The intervention did not have an impact on final grade averages or retention rates in comparing the treatment and control groups. Future research is needed to further explore the impact on these two measures. Past research on face-to-face attribution retraining is promising. Additional, longterm research, utilizing the distance learning environment, is needed to evaluate the effectiveness of such interventions for the online student. Self-efficacy, motivation, locus of control, academic success and persistence are influenced by a wide array of variables. Attribution retraining is an additional tool for colleges to add to their arsenal to further support and assist students to better succeed in school and in life. 


\section{References}

Allen, E., \& Seaman J. (2004). Entering the mainstream: The quality and extent of online education in the United States, 2003 and 2004. Needham, MA: Sloan-C. Retrieved from http://www.sloan-c.org/resources/entering_mainstream.pdf

Bandura, A. (1994). Self-efficacy. In V. S. Ramachaudran (Ed.), Encyclopedia of human behavior (Vol. 4, pp. 71-81). New York: Academic Press.

Berge, Z. \& Huang, Y. (2004, May). A model for sustainable student retention: A holistic perspective on the student dropout problem with special attention to e-learning. DEOSNEWS, 13(5). Retrieved January 15, 2007 from http://www.ed.psu.edu/acsde/deos/deosnews/deosnews13_5.pdf

Byers, A. (2000). Interaction: The key to successful distance learning. Paper presented at Ed-Media 2000 World Conference on Educational Multimedia, Hypermedia \& Telecommunications, Proceedings. Charlottesville, Virginia: Association for the Advancement of Computing in Education.

Carr, S. (2000). As distance education comes of age, the challenge is keeping the students. The Chronicle of Higher Education, 46(23), A39-A41.

Chen, S. (2005). Changing college students' psychological constructs of learning influences their academic performances. College Student Journal, 39(1), 48.

Dawson, T. (1997). A primer on experimental and quasi-experimental design. Paper presented at the annual meeting of the Southwest Educational Research Association, Austin. Retrieved January 252007 from http://ericae.net/ft/tamu/Expdes.HTM 
Diaz, D., \& Cartnal, R. (1999). Student's learning styles in two classes: Distance learning and equivalent on-campus. College Teaching, 47(4), 130-135.

Dille, B., \& Mezack, M. (1991). Identifying predictors of high risk among community college telecourse students. The American Journal of Distance Education, 5(1), 24-35.

Doctor, T. (2004). Does video-based and live attribution training improve college freshman performance on academic-based tasks? Unpublished doctoral dissertation, West Virginia University, Morgantown.

Dollinger, S. J. (2000). Locus of control and incidental learning: An application to college student success. College Student Journal, 34(4), 537-540.

Domino, G., \& Domino, M. (2006). Psychological testing: An introduction. New York: Cambridge University Press

Dresel, M., \& Haugwitz, M. (2006). Effectiveness of a computer based training approach to foster motivation and self-regulated learning during regular classroom instruction. Paper presented at the annual meeting of the American Educational Research Association. San Francisco, California.

Goel, M. (2002). Educational objectives and retention at two community colleges. Paper presented at the Annual Forum of the Association for Institutional Research 42nd, Toronto, Ontario, Canada.

Grimes, P., Millea, M., \& Woodruff, T. (2004). Grades - who's to blame? Student evaluation of teaching and locus of control. Journal of Economic Education, 4(2), 23-45. 
Haggbloom, S. J. (2002). The 100 most eminent psychologists of the 20th century. Review of General Psychology, 6,139-152.

Hall, N., Hladkyj, S., Perry, R., \& Ruthig, J. (2004). The role of attributional retraining and elaborative learning in college students' academic development. The Journal of Social Psychology, 144(6), 591-612.

Hall, S. (2005) Factors affecting university GPA of Maryland Community College transfer students who persist to graduation. Unpublished master's thesis, University of Maryland, College Park.

Heaperman, S., \& Sudweeks, F. (2002) Achieving self-efficacy in the virtual learning environment. ERIC, Retrieved March 2008, from http://eric.ed.gov/

Horan, J., Hackett, G., Kovalski, T., Tompkins-Bjorkman, A., \& Clark, G., (2000). Interactive career counseling on the Internet. Journal of Career Assessment, 8(1), 85-93.

Klatt, J. \& Taylor-Powell, E. (2005). Synthesis of Literature relative to Retrospective Pretest Design. Presentation to the 2005 Joint CES/AEA Conference, Toronto, Canada.

Keller, J., Goldman, J., \& Sutterer, J. (1978). Locus of control in relation to academic attitudes and performance in a personalized system of instruction course. Journal of Educational Psychology, 70(3), 414-421.

Lange, R.V. \& Tiggemann, M. (1980). Changes within the Australian population to more external control beliefs. Australian Psychologist, 15, 495-497.

Legerski, E., Cornwall, M., \& O'Neil, B. (2006). Changing locus of control: Steelworkers adjusting to forced unemployment. Social Forces, 84(3), 1521-1537. 
Liu, Y., Lavelle, E., \& Andris, J. ( 2002). Experimental effects of online instruction on locus of control. USDLA Journal [Online] 16(6). Retrieved February 3, 2007 from http://www.usdla.org/html/journal/JUN02_Issue/article02.html

Lotkowski, V. A., Robbins, S. B., \& Noeth, R. J. (2004). The role of academic and non-academic factors in improving college retention. Washington, DC: ACT policy report. (ERIC Document Reproduction Service No. ED485476).

Lumina Foundation. (2004). Lumina Foundation Focus: Addressing retention issues early. Retrieved February 1, 2007 from http://www.luminafoundation.org/publications/focus/addressingretention.html Lynch, S., Hurford, D., \& Cole, A. (2002). Parental enabling attitudes and locus of control of at-risk and honors students. Adolescence, 37(147) 527- 549.

Morris, L., Wu, S., \& Finnegan, C. (2005). Predicting retention in online general education courses. The American Journal of Distance Education, 19(1), 23-36.

Muse, H. (2005). At-risk factors for the community college web-based student. Paper presented at the $20^{\text {th }}$ Annual Conference on Distance Teaching and Learning. Retrieved March 6, 2007, from http://www.uwex.edu/disted/conference.

Nash, R. D. (2005). Course completion rates among distance learners: Identifying possible methods to improve retention. Online Journal of Distance Learning Administration, 8(4),1-26.

Nathawat, S. S., Singh, R., \& Singh, B. (1997). The effect of need for achievement on attributional style. Journal of Social Psychology, 137(1), 55-62. 
Neill, J. T. (2005). Locus of control - a class tutorial. [Electronic version]. Retrieved January 30, 2007 from (http://www.wilderdom.com/games/descriptions/LocusOfControlExercise.html).

Pantages, T. J., \& Creedon, C. F. (1978). Studies of college attrition: 1950-1975. Review of Educational Research, 48(1), 49-101.

Parker, A. (1999). A study of variables that predict dropout from distance education. International Journal of Educational Technology, 1(2), 55-61. Retrieved February 5, 2007, from http://www.outreach.uiuc.edu/ijet/v1n2/parker/index.html

Parker, A. (2003). Identifying predictors of academic persistence in distance education. Untied States Distance Learning Journal, 17(1). Retrieved August 23, 2006, from http://www.usdla.org/html/journal/JAN03_Issue/article06.html

Perry, R., \& Penner, K. (1990). Enhancing academic achievement in college students through attributional retraining and instruction. Journal of Educational Psychology, 82(2), 262-271.

Rotter, J. B. (1966). Generalized expectancies for internal versus external control of reinforcement. Psychological Monographs, 80. (Whole No. 609).

Schultz, C., \& Pomerantz, M. (1976). Achievement motivation, locus of control, and academic achievement behavior. Journal of Personality, 44(1), 38-51.

Schunk, D. (2003). Self efficacy for reading and writing: Influence of modeling, goal setting, and self evaluation. Reading \& Writing Quarterly, 19,159-172.

Schunk D. \& Zimmerman B. (2007). Influencing children's self-efficacy and selfregulation of reading and writing through modeling. Reading \& Writing Quarterly, 23(1), 7-25. 
Second Life. (2008). Retrieved March 15, 2008, from http://secondlife.com/whatis/ Serwatka, J. (2005) Improving retention in distance learning classes. International Journal of Instructional Technology and Distance Learning, 2(1). Retrieved September 1, 2006 from http://www.itdl.org/Journal/Jan_05/article06.htm

Stone, T. (1992). A new look at the role of locus of control in completion rates in distance education. Research in Distance Education: A Forum for Researchers in Distance Education, 4(2), 6-9.

Stover, C. (2005). Measuring - and understanding - student retention. Distance Education Report, 9(16), 1-7.

Tinto, V. (1993). (Ed.). Leaving college: Rethinking the causes and cures of student attrition $\left(2^{\text {nd }}\right.$ ed.). Chicago: The University of Chicago Press.

Tinto, V. (1998). Colleges and communities: Taking research on student persistence seriously. The Review of Higher Education, 21(2), 167-177.

Tinto, V. (1999). Taking retention seriously: Rethinking the first year of college. NACADA Journal, 19(2), 5-9.

Tinto, V. (2002). Establishing the conditions for student success. Paper presented at the 11th annual conference of the European Access Network, Prato, Italy.

Tsai, Y \& Perry, F (1975). Factors affecting academic performance and persistence among the Mexican American, the black and the Anglo students in a southwestern university. Paper presented at the Annual Meeting of the Southwestern Sociological Association, San Antonio, TX. 
Upcraft, M., \& Gardener, J., \& Associates. (1989). The freshman year experience: Helping students survive and succeed in college. San Francisco: Jossey-Bass Publishers.

Valentine, D. (2002). Distance learning: Promises, problems, and possibilities. The Online Journal of Distance Learning Administration, V(III), Fall 2002. Retrieved January 28,2007 , from http://www.westga.edu/ distance/ojdla/fall53/valentine53.html.

Warring, D. (1991). Attributions and the implications of strategy in the attribution model. Journal of Instructional Psychology, 18(3), 179-186.

Weiner, B. (1979). A theory of motivation for some classroom experiences. Journal of Educational Psychology, 7(1), 1-25.

Whipp, J., \& Chiarelli, S. (2004). Self-regulation in a web-based course: A case study. Educational Technology Research and Development, 52(4), 5-22.

Wild, L., \& Ebbers, L. (2002). Rethinking student retention in community college. Community College Journal of Research and Practice, 26, 503-519.

Wilson, T. D., \& Linville, P. W. (1982). Improving the academic performance of college freshmen: Attribution therapy revisited. Journal of Personality and Social Psychology, 42, 367-376.

Wilson, T., \& Linville, P. (1985). Improving the performance of college freshmen with attributional techniques. Journal of Personality and Social Psychology, 49, 287293.

Zamani, E. (2000). Sources and information regarding effective retention strategies for students of color. New Directions for Community Colleges, 28(4), 95-104. 
APPENDIX A

Course Outline for EDU202 Instructional Technology

\section{CaDU202 Instructional Technology}

\section{COURSE OUTLINE}

Semester/Session Spring 2007

- Instructor Name(s): Bonnie Ordonez

- Instructor Telephone(s): (412)469-6343

- Instructor E-Mail Address(es): bordonez@acd.ccac.edu

- Instructor Office Hours:

$\begin{array}{ll}\mathrm{M}- & 9: 40-10: 45 \mathrm{am} \\ & 12: 05-1: 10 \mathrm{pm} \\ \mathrm{T}- & 9: 45-10: 45 \mathrm{am} \\ \mathrm{W}- & 9: 45-10: 45 \mathrm{am} \\ \text { R. }- & 9: 45-10: 45 \mathrm{am}\end{array}$

- Instructor Office Location(s): B606 South Campus

- Course Number: EDU202

- Current Catalog Course Title: Instructional Technology

- Course Credit(s): 3 Lecture hours: Lab hours: Other hours:

- Prerequisite(s): NONE

- Co-requisite(s):

- Current Catalog Description:

This is a course for students planning careers in education or other fields where instructional technology may be required. The students will learn to prepare and use a wide range of media for instruction. 
- Class Meeting Times \& Locations: IN85/IN86 Blackboard

- Course Objectives: The students will:

- Define and apply technology integration theories and teaching methods to the production of instructional media.

- Utilize instructional resource material and technology appropriate to the $\mathrm{K}-12$ classroom.

- Retrieve websites and evaluate for instructional quality.

- Locate and analyze instructional resources.

- Develop an educational portfolio by incorporating instructional technology items.

- Use various types of instructional media for teaching

- Design media for presentation and instructional purposes, including visual, verbal and auditory media.

- Discuss various techniques for media production

- Evaluate various types of instructional media

- Utilize and integrate the office suite (Word, PowerPoint, Excel, and Access)

- Develop a web quest

- Create movies for use in the K-12 classroom

- Discuss the issues and regulations surrounding instructional technologies

- Teaching Methods:

PowerPoint

Discussion

Online Activities

\section{- Materials and Resources:}

Required Text(s): Roblyer, M.D. (2006). Integrating Educational Technology into Teaching $4^{\text {th }}$ ed. Pearson, Merrill, Prentice Hall. ISBN 0-13-119572-7

\section{- Evaluation Plan:}

Discussion board postings

Projects

Exam

Weekly assignments

\section{- Other Policies and Procedures:}

Online Decorum: Students are expected to maintain a professional attitude in using email and the discussion board. All correspondence should be completed in proper English (no IM lingo) and demonstrate respect. Abuse of email or the discussion board will result in academic penalty at the instructor's discretion.

Late Assignments: Late assignments will not be accepted and given an automatic "0". 
Plagiarism: Plagiarism is the act of using someone else's written words without quotation and citation. Any assignment containing excerpts from someone else's work will be automatically given a "0" with no opportunity for resubmission.

The Community College of Allegheny County (CCAC) makes every effort to provide reasonable accommodations for students with disabilities. Questions about services and procedures for students with disabilities should be directed to the Office of Supportive Services at your campus.

During the semester/session, reasonable changes to the course outline may be academically appropriate; however students will be notified of these adjustments in a timely manner.

- Fonnie Ordonez

Instructor Signature
$1 / 29 / 07$

Date

Rpb 9/92; 11/05/03

Approved by Academic Deans 11/19/200 


\section{APPENDIX B}

\section{Impact of Attribution Retraining with Students Enrolled in an Internet-based Instructional Technology course at a Community College}

\section{Cover letter}

This class section has been chosen for participation in a research study being conducted to fulfill the requirements of Doctor of Education in Technology Education at West Virginia University. The purpose of the study is to determine if how a student attributes their success and failure impacts their grade and course retention. In addition, the study will look at an intervention technique that determines if attributions can be altered. All responses will be kept anonymous. Blackboard allows for surveys to be accessed and completed anonymously. As Blackboard is a password protected course site, the researcher (instructor) is the only one who will have access to the surveys. Your participation is voluntary and in no way will non-participation impact your grade or standing in the course. You may choose to withdraw from the study at any time. When completing the surveys, you do not have to answer every question. A copy of the study will be available upon request once the dissertation is completed.

This research is being conducted in accordance with WVU dissertation requirements and WVU Institutional Review Board (IRB). The information being gathered (surveys, questionnaires, and data analysis will be done by the Co-investigator of the study, under the supervision of the Primary Investigator.

\section{CO-INVESTIGATOR PRIMARY CONTACT}

Bonnie Ordonez

CCAC, B- 606, South Campus 
1750 Clairton Road (Route 885)

West Mifflin, Pennsylvania 15122-3097

(412)469-6343

bordonez@ccac.edu

PRIMARY INVESTIGATOR:

Dr. Neal Shambaugh

PO Box 6122

Morgantown, WV, 26506

(304) 293-2060

neal.shambaugh@mail.wvu.edu 


\section{APPENDIX C}

\section{Rotter's Locus of Control Scale}

1. a. Children get into trouble because their patents punish them too much.

b. The trouble with most children nowadays is that their parents are too easy with them.

2. a. Many of the unhappy things in people's lives are partly due to bad luck.

b. People's misfortunes result from the mistakes they make.

3. a. One of the major reasons why we have wars is because people don't take enough interest in politics.

b. There will always be wars, no matter how hard people try to prevent them.

4. a. In the long run people get the respect they deserve in this world

b. Unfortunately, an individual's worth often passes unrecognized no matter how hard he tries

5. a. The idea that teachers are unfair to students is nonsense.

b. Most students don't realize the extent to which their grades are influenced by accidental happenings.

6. a. Without the right breaks one cannot be an effective leader.

b. Capable people who fail to become leaders hive not taken advantage of their opportunities.

7. a. No matter how hard you try some people just don't like you.

b. People who can't get others to like them don't understand how to get along with others.

8. a. Heredity plays the major role in determining one's personality 
b. It is one's experiences in life which determine what they're like.

9. a. I have often found that what is going to happen will happen.

b. Trusting to fate has never turned out as well for me as making a decision to take a definite course of action.

10. a. In the case of the well prepared student there is rarely if ever such a thing as an unfair test.

b. Many times exam questions tend to be so unrelated to course work that studying in really useless.

11. a. Becoming a success is a matter of hard work, hick has little or nothing to do with it.

b. Getting a good job depends mainly on being in the right place at the. right time.

12. a. The average citizen can have an influence in government decisions.

b. This world is run by the few people in power, and there is not much the little guy can do about it.

13. a. When I make plans, I am almost certain that I can make them work.

b. It is not always wise to plan too far ahead because many things turn out to- be a matter of good or bad fortune anyhow.

14. a. There are certain people who are just no good.

b. There is some good in everybody.

15. a. In my case getting what I want has little or nothing to do with luck. b. Many times we might just as well decide what to do by flipping a coin. 
16. a. Who gets to be the boss often depends on who was lucky enough to be in the right place first.

b. Getting people to do the right thing depends upon ability, luck has little or nothing to do with it.

17. a. As far as world affairs are concerned, most of us are the victims of forces we can neither understand, nor control.

b. By taking an active part in political and social affairs the people can control world events.

18. a. Most people don't realize the extent to which their lives are controlled by accidental happenings.

b. There really is no such thing as "luck."

19. a. One should always be willing to admit mistakes.

b. It is usually best to cover up one's mistakes.

20. a. It is hard to know whether or not a person really likes you.

b. How many friends you have depends upon how nice a person you are.

21. a. In the long run the bad things that happen to us are balanced by the good ones.

b. Most misfortunes are the result of lack of ability, ignorance, laziness, or all three.

22. a. With enough effort we can wipe out political corruption.

b. It is difficult for people to have much control over the things politicians do in office.

23. a. Sometimes I can't understand how teachers arrive at the grades they give. 
b. There is a direct connection between how hard 1 study and the grades I get.

24. a. A good leader expects people to decide for themselves what they should do.

b. A good leader makes it clear to everybody what their jobs are.

25. a. Many times I feel that I have little influence over the things that happen to me.

b. It is impossible for me to believe that chance or luck plays an important role in my life.

26. a. People are lonely because they don't try to be friendly.

b. There's not much use in trying too hard to please people, if they like you, they like you.

27. a. There is too much emphasis on athletics in high school.

b. Team sports are an excellent way to build character.

28. a. What happens to me is my own doing.

b. Sometimes I feel that I don't have enough control over the direction my life is taking.

29. a. Most of the time I can't understand why politicians behave the way they do.

b. In the long run the people are responsible for bad government on a national as well as on a local level.

\section{Scoring:}

One point was given for each of the following:

3.b, 4.b, 5.b, 10.b, 11.b, 12.b, 13.b, 15.b, 22.b, 26.b, 28.b,

2.a, 6.a, 7.a, 9.a, 16.a, 17.a, 18.a, 20.a, 21.a, 23.a, 25.a, 29.a.

0-3 - Internal Locus of Control (extreme)

4-11 - Internal Locus of Control (healthy)

12-23 - External Locus of Control 


\section{APPENDIX D}

Just Think It: Interactive Multimedia Program

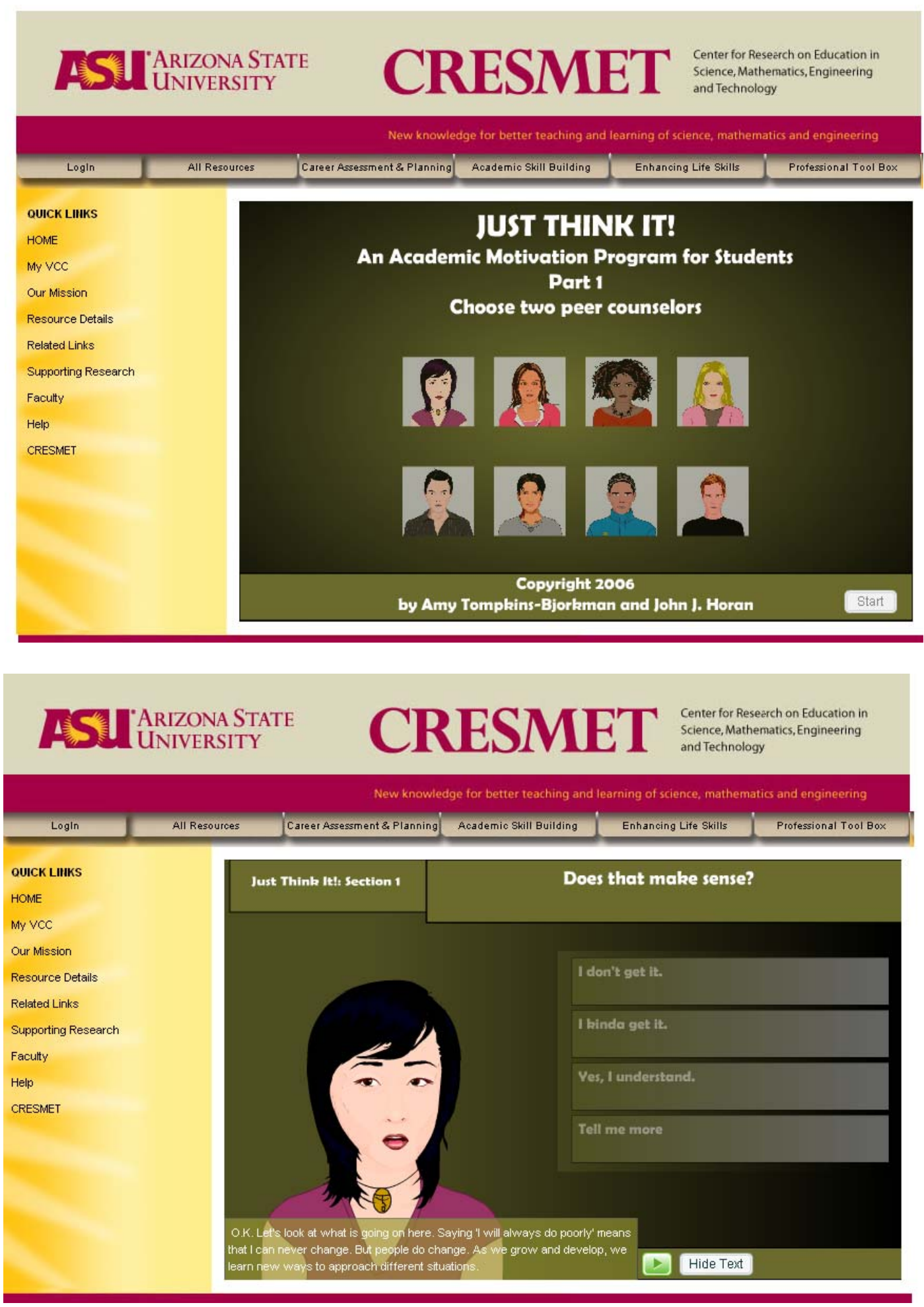




\section{APPENDIX E}

Assignment Sheet and Multimedia Software Evaluation Form

\section{EDU202 Instructional Technology}

Multimedia Site Review

Go to this site: http://vcc.asu.edu/think it/index.shtml

Review the following: Experience Session 1 of Just Think It! And Experience Session 2 of Just Think It! Go through each program from beginning to end. Answer questions honestly and pay close attention to the content, layout, design, and effectiveness of the programs.

Complete the following:

O In Microsoft Word type a detailed summary of the content of each session.

○ Using the evaluation sheets provided below, evaluate the sessions. The sessions are similar in layout so you only need one set of evaluation forms for both.

○ Upload the word document and evaluation forms.

Upload to the Assignment Window VIA BLACKBOARD ON OR BEFORE DUE DATE 


\section{"Multimedia Software Evaluation Checklist" \\ Assessment of Commercial/Published Products \\ Pick 2 Y/N}

\section{Instructional planning}

1. Target audience and prerequisite skills are specified.

Comments:

YES NO

\section{Support}

2. Computer hardware and software requirements are specified.

Comments:

YES NO

\section{Instructional adequacy}

3. Instructional objectives are clearly stated. Practice activities are provided that actively involve the learner. Instructional activities needed to complete tasks are made explicit.

\section{Comments:}

YES NO

\section{Information content}

4. Information is current and accurately represents the topic. Examples, practice exercises, and feedback are meaningful and relevant.

Comments:

YES NO

\section{Information reliability}

5. Information is accurate, i.e., presented in a truthful, valid way. Comments:

YES NO

\section{Clear, concise, and unbiased language}

6. Courseware content is presented clearly. (Text, pictorial, graphical, auditory, and video information are all presented clearly.)

YES NO

\section{Comments:}

\section{Interface design and navigation}

7. Courseware screen elements (titles, text areas, navigation buttons, etc.) are easy to understand. Directions are understandable.

YES NO

\section{Comments:}

\section{Feedback and interactivity}

8. If tests are present, they are matched to objectives. Feedback is appropriate to content, learning tasks, learner response, and learning environment.

YES NO 


\section{Comments:}

\section{Evidence of Effectiveness}

9. During student use of courseware, there was evidence of learning/performance gains. The courseware supplies information to teachers and students on how it measures student learning.

YES NO

\section{Comments:}

Multimedia Software Evaluation Checklist Detail Hands On With Technology Page 2

\section{"Checklist for Assessing Multimedia Products" Assessment of Student Products \\ Pick 2 Y/N}

\section{Content YES NO}

1. All information is the most current, up-to-date available. YES NO

2. All information is factually correct. YES NO

3. Content is free from typos and misspellings, and from punctuation and grammatical errors. YES NO

4. No ethnic, slang, or rude names are used; content is presented in a professional way. YES NO

5. No questionable vocabulary, slang terms, or curse words are used. YES NO

6 . Content sources (including sources of graphics) are properly referenced. YES NO

\section{Instructional Design YES NO}

7. Instructional objectives are clear; the instructional purpose is aligned with school curriculum, rather than being for entertainment. YES NO

8. All necessary information is provided in the product to make concepts clear; users will be able to understand what is being presented from the information provided. YES NO

9. If tests or other assessments are provided, they are matched directly to objectives. YES NO

10. To add interest and motivation for users, information is presented in an innovative and creative

Way. YES NO

\section{Organization and Navigation YES NO}

11. Screens are designed for eases Navigation; it is clear how to get to and from various parts of the Product. YES NO

12. To aid navigation and use, the product has a consistent look and feel throughout. YES NO

13. Buttons and links all work as indicated. YES NO

\section{Appearance YES NO}

14. Use of varying fonts and type sizes is controlled, so as not to interfere with readability. YES NO

15. Type is large enough to read when projected. YES NO

16. Color contrasts with background for easy reading. YES NO 
17. Bold or plain style is used for main text; no shadow and outline if text is more than a few words. Fancy fonts and type styles are readable. YES NO

18. Only brief main ideas are listed in a single frame, rather than paragraphs of text. YES NO

\section{Graphics, Videos, and Sound YES NO}

19. Graphics, videos, and sound are included as appropriate to help communicate information on the topic; they are not included just for show. YES NO 20. No obscene or rude graphics or visuals are included. YES NO 21. Use of graphics (e.g., animations, screen changes) is controlled and does not distract from reading. YES NO

22. Pictures and sounds associated with buttons and links are appropriate to the purposes and content of the frames. YES NO 